\title{
Upland streamwater nitrate dynamics across decadal to sub-daily timescales: a case study of Plynlimon, Wales
}

\author{
S. J. Halliday ${ }^{1}$, R. A. Skeffington ${ }^{1}$, A. J. Wade ${ }^{1}$, C. Neal ${ }^{2}$, B. Reynolds ${ }^{3}$, D. Norris ${ }^{3}$, and J. W. Kirchner ${ }^{4,5}$ \\ ${ }^{1}$ Department of Geography and Environmental Science, University of Reading, Reading, RG6 6AB, UK \\ ${ }^{2}$ Centre for Ecology and Hydrology, Maclean Building, Crowmarsh Gifford, Wallingford, Oxon, OX11 8BB, UK \\ ${ }^{3}$ Centre for Ecology and Hydrology, Environment Centre Wales, Deiniol Road, Bangor, Gwynedd, LL57 2UW, UK \\ ${ }^{4}$ Swiss Federal Research Institute WSL, Zürcherstrasse 111, 8903 Birmensdorf, Switzerland \\ ${ }^{5}$ Department of Environmental Systems Science, ETH Zürich, Universitätsstrasse 16, 8092 Zürich, Switzerland
}

Correspondence to: S. J. Halliday (s.j.halliday@ reading.ac.uk)

Received: 16 July 2013 - Published in Biogeosciences Discuss.: 8 August 2013

Revised: 30 October 2013 - Accepted: 6 November 2013 - Published: 9 December 2013

\begin{abstract}
Streamwater nitrate dynamics in the River Hafren, Plynlimon, mid-Wales were investigated over decadal to sub-daily timescales using a range of statistical techniques. Long-term data were derived from weekly grab samples (1984-2010) and high-frequency data from 7-hourly samples (2007-2009) both measured at two sites: a headwater stream draining moorland and a downstream site below plantation forest. This study is one of the first to analyse upland streamwater nitrate dynamics across such a wide range of timescales and report on the principal mechanisms identified. The data analysis provided no clear evidence that the long-term decline in streamwater nitrate concentrations was related to a decline in atmospheric deposition alone, because nitrogen deposition first increased and then decreased during the study period. Increased streamwater temperature and denitrification may also have contributed to the decline in stream nitrate concentrations, the former through increased $\mathrm{N}$ uptake rates and the latter resultant from increased dissolved organic carbon concentrations. Strong seasonal cycles, with concentration minimums in the summer, were driven by seasonal flow minimums and seasonal biological activity enhancing nitrate uptake. Complex diurnal dynamics were observed, with seasonal changes in phase and amplitude of the cycling, and the diurnal dynamics were variable along the river. At the moorland site, a regular daily cycle, with minimum concentrations in the early afternoon, corresponding with peak air temperatures, indicated the importance of instream biological processing. At the downstream site, the diurnal dynamics were a composite
\end{abstract}

signal, resultant from advection, dispersion and nitrate processing in the soils of the lower catchment. The diurnal streamwater nitrate dynamics were also affected by drought conditions. Enhanced diurnal cycling in Spring 2007 was attributed to increased nitrate availability in the post-drought period as well as low flow rates and high temperatures over this period. The combination of high-frequency short-term measurements and long-term monitoring provides a powerful tool for increasing understanding of the controls of element fluxes and concentrations in surface waters.

\section{Introduction}

Nitrogen $(\mathrm{N})$ is a key nutrient in river systems worldwide, but an over-enrichment of $\mathrm{N}$ can lead to problems of eutrophication, acidification and reduced biodiversity (e.g. Dise et al., 2009; Galloway et al., 2004; Jarvie et al., 1998; Neal and Jarvie 2005; Smith et al., 1999; Stevens et al., 2006; Sutton et al., 2011; UK-NEA 2011; Wright et al., 2001). Within aquatic environments, nitrate $\left(\mathrm{NO}_{3}\right)$ is generally the dominant $\mathrm{N}$ fraction, with dissolved organic $\mathrm{N}$ (DON) also a critical component in certain systems, particularly on a seasonal basis (Chapman et al., 2001; Reynolds and Edwards, 1995; Sutton et al., 2011). $\mathrm{NO}_{3}$ has been studied extensively across the world, using process studies at single sites, long-term monitoring of individual catchments such as Hubbard Brook in the USA (Likens, 2004), and integrated networks of monitoring sites such as the US Long-Term 
Ecological Research Network (http://www.lternet.edu/) and the UK Environmental Change Network (http://www.ecn.ac. uk). These studies have yielded important information on the $\mathrm{N}$ cycle but key areas of uncertainty remain. In particular, there is continued debate about the long-term effect of $\mathrm{N}$ deposition on catchment $\mathrm{N}$ processing within the context of other environmental variables, such as air temperature and soil and streamwater carbon (C). The relative importance of soil and instream processing in the determination of instream $\mathrm{N}$ concentrations also remains poorly understood.

Streamwater $\mathrm{NO}_{3}$ concentrations in forested catchments in New Hampshire, USA have declined remarkably over the last $30 \mathrm{yr}$ (e.g. Goodale et al., 2003; Bernal et al., 2012). Commensurate with this decline was a very modest (and not statistically significant) decline in atmospheric $\mathrm{N}$ deposition (Bernal et al., 2012), and given this slight reduction only, the reduction in forest growth and an apparent accumulation of $\mathrm{N}$ in the terrestrial catchment were expected to increase stream $\mathrm{N}$ concentrations. Possible reasons for this unexpected decrease in streamwater $\mathrm{NO}_{3}$ concentrations are debated and hard to distinguish given current monitoring regimes. The reasons offered include climate variability affecting soil temperature regimes, both gradually and in relation to the frequency of extreme events such as frosts; forest disturbances such as insect defoliation and ice storms; changes in forest species composition; long-term responses to forest harvesting; and subtle changes in stream $\mathrm{N}$ processing due, for instance, to more organic debris dams in the rivers, leading to increases in denitrification and particulate N export (see e.g. Goodale et al., 2003; Bernhardt et al., 2005; Bernal et al., 2012). Clearly, work is needed to better understand the relationship between deposition and streamwater concentrations.

Assumptions that $\mathrm{N}$ cycle processes in the terrestrial catchment are the overwhelming influence on stream $\mathrm{NO}_{3}$ concentrations and export rates, and that instream processing is insignificant, no longer seem tenable (Bernhardt et al., 2005). A meta-analysis of studies in which both soil solution and adjacent stream $\mathrm{NO}_{3}$ concentrations were measured demonstrated that, in undisturbed forested catchments, stream $\mathrm{NO}_{3}$ concentrations typically were about half of those in soil solutions below the rooting zone (Sudduth et al., 2013). This result indicates the importance of instream or near-stream $\mathrm{N}$ removal mechanisms. A recent review of river bed $\mathrm{N}$ removal mechanisms demonstrated the potentially large flux transfers between the water column and hyporheic zone, as well as a close connection of the $\mathrm{C}$ and $\mathrm{N}$ cycles (Trimmer et al., 2012). Thus, work is needed to better understand the role of soil, groundwater and instream processes in controlling the observed water chemistry.

To characterise instream $\mathrm{NO}_{3}$ dynamics and their response to anthropogenic forcing and climatic variability, it is necessary to sample at frequencies capable of capturing the abiotic and biotic controls on water quality (Hood et al., 2006; Kirchner et al., 2004; Pellerin et al., 2009).
Traditionally, water quality monitoring programmes involve discrete grab sampling at weekly to monthly intervals; however water quality determinands are known to vary considerably over much shorter timescales (e.g. Herrman et al., 2008; Nimick et al., 2011; Palmer-Felgate et al., 2008; Pellerin et al., 2012). Those studies that measure sub-daily instream $\mathrm{NO}_{3}$ dynamics tend to be based on short-term monitoring schemes, spanning a few days or specific months (e.g. Duff et al., 2008; Mulholland et al., 2006; Parker et al., 2007; Pellerin et al., 2009; Scholefield et al., 2005). These studies have also tended to focus on single-site installations and often measurements have only been made during one hydrological year (e.g. Chapin et al., 2004; Ferrant et al., 2012; Parker et al., 2007). Whilst these studies are pioneering in many ways, their short durations make the evaluation of the observed sub-daily dynamics and their importance to the overall $\mathrm{NO}_{3}$ cycle difficult to quantify, because it is not possible to place the dynamics within the wider context of $\mathrm{NO}_{3}$ variability.

The aim of this paper is to help advance the understanding of the controls on $\mathrm{NO}_{3}$ concentrations in streams, specifically their variation along the river system across a range of timescales from decades to hours. This was achieved through a detailed investigation of both long-term $\mathrm{NO}_{3}$ measurements and periods of high-frequency $\mathrm{NO}_{3}$ measurements for two sites on the River Hafren at Plynlimon in Wales. The long-term data were derived from weekly grab samples (1984-2010) and high-frequency data from 7-hourly samples during 2007-2009 (Neal et al., 2011, 2012, 2013a, b, c). The Hafren data set offers a unique ability to assess aspects of $\mathrm{NO}_{3}$ cycling which previous data sets have not allowed. The long-term hydrochemical records allow the high-frequency dynamics observed within the 7-hourly data set to be placed within the context of long-term hydrological changes, and how the instream dynamics are changing year to year. In addition, the collection of data from two sites on the same river also allows an evaluation of how the high-frequency nutrient dynamics change along the system. The paper discusses what can be concluded about the principal mechanisms controlling the observed streamwater $\mathrm{NO}_{3}$ dynamics along the River Hafren using both low- and high-frequency data, with particular focus on the controls on long-term changes in the streamwater nitrate concentrations and the relative importance of soil and instream processes in controlling the observed water chemistry.

\section{Study area and data resources}

\subsection{Study area}

All the data presented in this paper were collected by the Centre for Ecology and Hydrology (CEH) in the upper River Severn, Plynlimon, mid-Wales (Fig. 1 and Table 1). The hydrology and hydrochemistry of this catchment have been 
Table 1. Plynlimon monitoring programme details.

\begin{tabular}{llllll}
\hline Monitoring point & Type of monitoring & Frequency & Duration & Start & End \\
\hline Carreg Wen & $\begin{array}{l}\text { Cloud water volume } \\
\text { and quality }\end{array}$ & Weekly & $21 \mathrm{yr}$ & $25 / 09 / 1990$ & Ongoing \\
& $\begin{array}{l}\text { Rainfall water volume } \\
\text { and quality }\end{array}$ & Weekly & $28 \mathrm{yr}$ & $10 / 05 / 1983$ & Ongoing \\
& Air temperature & 7-hourly & $1.9 \mathrm{yr}$ & $06 / 03 / 2007$ & $27 / 01 / 2009$ \\
& Incoming solar radiation & & $36 \mathrm{yr}$ & $03 / 01 / 1976$ & Ongoing \\
& Streamwater quality & Weekly & $21 \mathrm{yr}$ & $17 / 07 / 1990$ & Ongoing \\
& & 7 -hourly & $1.9 \mathrm{yr}$ & $06 / 03 / 2007$ & $27 / 01 / 2009$ \\
& Flow & 15 min & $6 \mathrm{yr}$ & $03 / 02 / 2005$ & Ongoing \\
\hline \multirow{2}{*}{ Upper Hafren } & Streamwater quality & Weekly & $28 \mathrm{yr}$ & $10 / 05 / 1983$ & Ongoing \\
& \multirow{2}{*}{ Fower Hafren } & 7-hourly & $1 \mathrm{yr}$ & $06 / 03 / 2007$ & $11 / 03 / 2008$ \\
& Flow & 15 min & $36 \mathrm{yr}$ & $01 / 01 / 76$ & Ongoing \\
\hline
\end{tabular}

studied extensively over the last 40 years (Green and Marsh, 1997; Marc and Robinson 2007; Neal, 1997, 2004). This study focuses on a small stream, the Hafren, which drains one of the main subcatchments of the Plynlimon catchment and forms the headwaters of the River Severn (Neal et al., 2001; Shand et al., 2007, 2005).

The Hafren catchment has an area of $3.6 \mathrm{~km}^{2}$ (of which the Upper Hafren is $1.2 \mathrm{~km}^{2}$ ) with an altitudinal range of 355-670 m (Brandt et al., 2004; Marsh and Hannaford, 2008). The bedrock geology is base-poor and comprises fractured Lower Palaeozoic slate, mudstone, greywacke and sandstone (Foster et al., 2001; Godsey et al., 2010). The landscape has been influenced by Quaternary glaciation, with periglacial activity leaving remnants of locally derived overlying boulder clay and till (Brandt et al., 2004; Neal et al., 2010). The predominant soils are stagnopodzols, but acidic peat, acid brown earths and stagnogleys also occur, and are typically less than $1 \mathrm{~m}$ thick (Foster et al., 2001; Neal et al., 2005). Peat erosion has also resulted in significant hag formation in the upper reaches of the catchment (Neal et al., 2010).

The catchment is divided into two subcatchments: the Upper and Lower Hafren (Fig. 1). The Upper Hafren is predominately semi-natural moorland with areas of low intensity sheep grazing (Fig. 1, P1; Neal et al., 2010). No fertilisers are applied and the land is not actively managed. The vegetation cover is predominantly a dwarf shrub heath community, dominated by Calluna vulgaris and Eriophorum spp., with acid grass species, Nardus stricta and Festuca spp., on steeper slopes and gullies (Fig. 1). The whole sub-catchment has been designated as a Site of Special Scientific Interest. The lower half of the catchment is first-generation plantation forestry, consisting of mainly Picea sitchensis (Sitka spruce) (Fig. 1, P2-4). The catchment was planted in several phases between 1942 and 1964 and, although no nitrogen fertilisation has taken place, the forest received aerial applications of potash $\left(200 \mathrm{~kg} \mathrm{ha}^{-1}\right)$ and phosphate $\left(375 \mathrm{~kg} \mathrm{ha}^{-1}\right)$ between September and November 1974 (Neal et al., 2010; Newson, 1976; Reynolds et al., 1989). Over the last $25 \mathrm{yr}$ the Lower Hafren catchment has been thinned and clear-felled in several phases, with cleared areas replanted with juvenile Sitka spruce (Neal et al., 2005, 2011; Whitehead et al., 2004). There is no human habitation in the catchments and no registered consented discharges.

The Hafren River channel is shallow, rocky, steep and irregular (Fig. 1; Newson and Harrison, 1978). The stream bed substrate consists largely of boulders, cobbles, pebbles and exposed bedrock (Fig. 1; Kirby et al., 1991; Newson and Harrison, 1978). The aquatic vegetation of the system has been studied, throughout the last twenty years, as part of the UK Acid Waters Monitoring Network (Kernan et al., 2010). Throughout this time, the epilithic diatom community has been dominated by one acidobiontic species, optimal $\mathrm{pH}$ $<5.5$, Eunotia exigua, with Tabellaria flocculosa becoming increasing prevalent since 2005 and Fragilaria virescens present since 2008 (Kelly et al., 2005; Kernan et al., 2010; Shilland et al., 2012). Under the EU Water Framework Directive (WFD) the river is classified as "high" status (the top category) for its diatom communities (Ecological Quality Ratio $(\mathrm{EQR})=<0.93)$. This means that, based on measurements of River Trophic Diatom Index, the River Hafren diatom community is close to the natural state anticipated in an undisturbed system (WFD, 2008). Recent work by Ledger and Hildrew (2005) identified cyanobacteria in the river. Filamentous green algae have been present on the river regularly since 2005 and the aquatic moss Hyocomium armoricum has also been identified (Kernan et al., 2010; Shilland et al., 2012). The aquatic macrophyte community is largely limited to Scapania undulata, an acid tolerant leafy liverwort species (Kernan et al., 2010). 

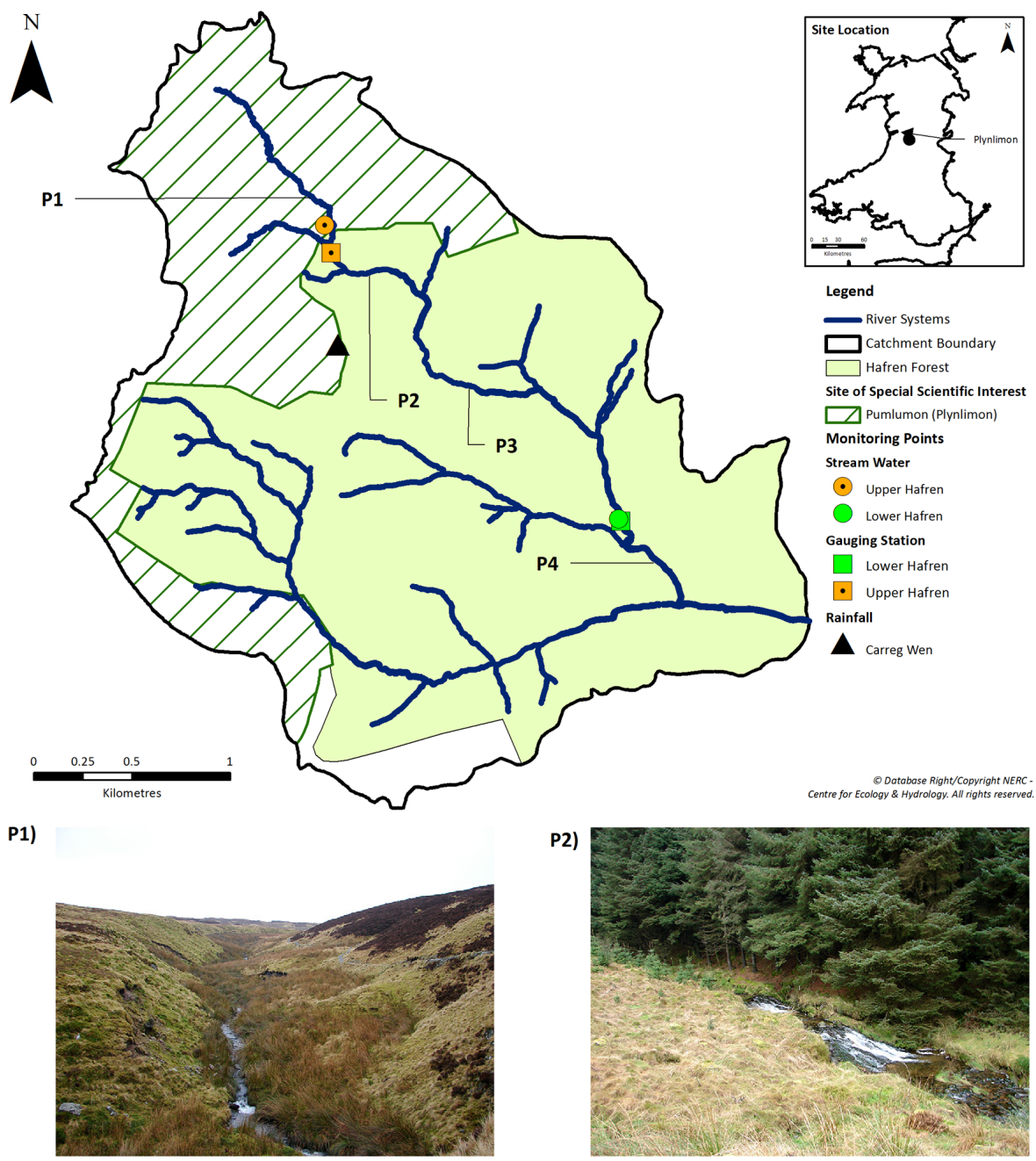

Legend

$\square$ River Systems Hafren Forest Site of Special Scientific Interest $\square$ Pumlumon (Plynlimon) Monitoring Points
Stream Water Upper Hafren Lower Hafren Gauging Station

Gauging Station
$\square \quad$ Lower Hafren - Upper Hafren Rainfall

P3)

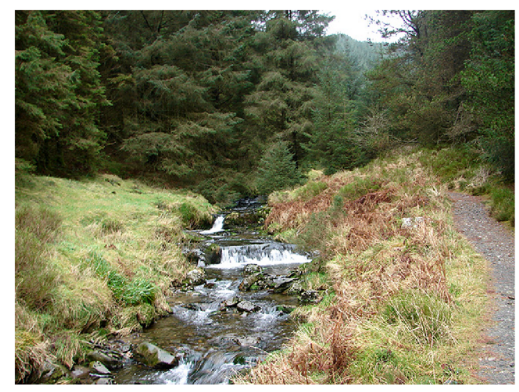

P2

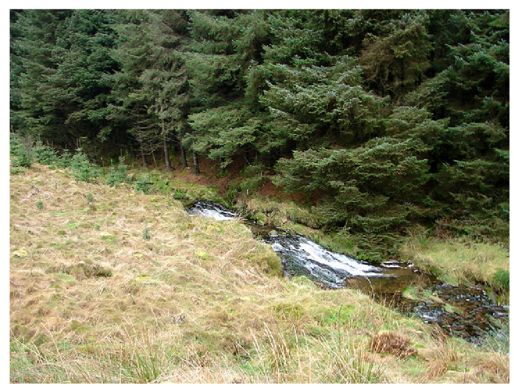

P4)

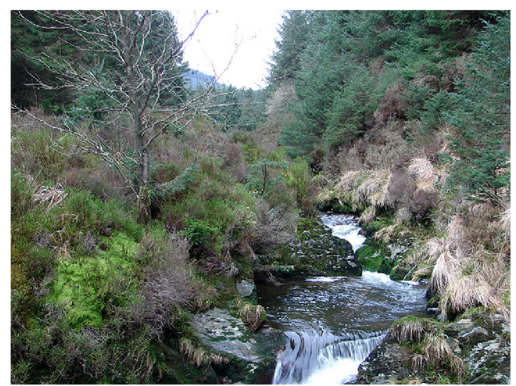

Fig. 1. Plynlimon catchment study area (Brandt et al., 2004). Photographs of the Hafren catchment taken on the 15/01/2009 by John Lucas and licensed for reuse under this Creative Commons Licence: (P1) the River Hafren upstream of the Upper Hafren monitoring point, picture looks upstream towards the source of the river (SN827893), (P2) the River Hafren downstream of the Upper Hafren Flume (SN828889), (P3) the River Hafren within the Hafren forest, picture looks upstream towards the steep valley of Graig Wen (SN835883), (P4) the Severn downstream of the Hafren Flume, picture looks upstream from a footbridge over the river (SN844874).

\subsection{Environmental conditions}

Situated on the upper slopes of Pumlumon Fawr, $24 \mathrm{~km}$ inland from the Irish Sea, the catchment has a temperate maritime climate dominated by westerly frontal systems. Atmospheric deposition is largely derived from sea salts and is relatively unpolluted (Reynolds et al., 1999). Mean wet $\mathrm{N}$ deposition was $6.1\left(\mathrm{NO}_{3}\right)$ and $9.1\left(\mathrm{NH}_{4}\right) \mathrm{kg} \mathrm{Nha}^{-1} \mathrm{yr}^{-1}$ (2007-2009) derived from long-range transport (Department for Environment, Food and Rural Affairs (DEFRA), 2012). Pembroke Power Station (located $80 \mathrm{~km}$ to the southwest) may have also contributed to atmospheric deposition before 

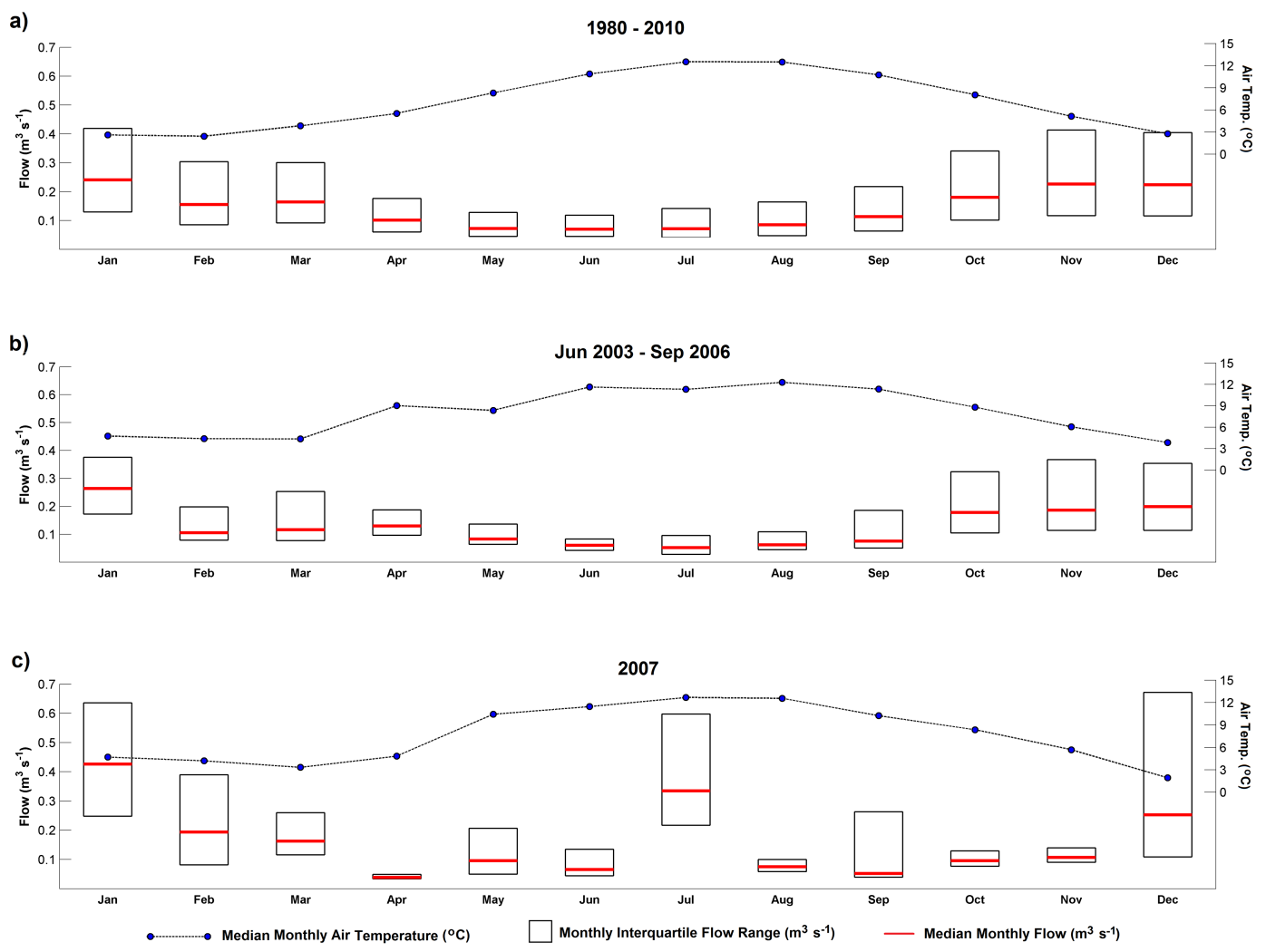

Fig. 2. Seasonal flow and air temperature patterns for the Hafren catchment, with the interquartile range and median flow for each month based on the $15 \mathrm{~min}$ flow record recorded at the Lower Hafren gauging station, and the median air temperature for each month based on the hourly temperature record recorded at Carreg Wen AWS shown: (a) long-term average, 1980-2010, (b) average conditions during the 2003-2006 drought, June 2003 to September 2006, (c) conditions during the first year of the high-frequency monitoring scheme, 2007.

it ceased generating electricity in 1997 (RWE npower, 2012). Between 1980 and 2010, mean annual precipitation and air temperature were $2600 \mathrm{~mm} \mathrm{yr}^{-1}$ and $7^{\circ} \mathrm{C}$, respectively, at the Carreg Wen Automatic Weather Station (AWS) (Fig. 1). Annual evapotranspiration losses were estimated to be between 500 and $700 \mathrm{~mm} \mathrm{yr}^{-1}$ (Hudson et al., 1997a). Flows respond rapidly to rainfall events, varying over two orders of magnitude from 0.01 to $7.3 \mathrm{~m}^{3} \mathrm{~s}^{-1}$ (based on the Lower Hafren gauging station flow record between 1980 and 2010). Between 1980 and 2010, median flow at the Lower Hafren gauging station was $0.13 \mathrm{~m}^{3} \mathrm{~s}^{-1}$. Flow and air temperature exhibited seasonal patterns with flows lowest in the summer months when air temperature is highest (Fig. 2).

Prior to the commencement of the high-frequency monitoring scheme in March 2007, the Plynlimon catchment experienced a prolonged period of below-average rainfall. At Plynlimon, between June 2003 and September 2006, the monthly rainfall volumes recorded at the Carreg Wen AWS were on average $12 \%$ lower than the long-term monthly rainfall volumes (1980-2010), with differences of $67 \%$ in August 2003 and $65 \%$ in June 2006. As a result, recorded flows at the Lower Hafren gauging station were significantly lower than long-term average flows over this period (Fig. 2).
Air temperatures were also elevated during this period and remained high into early 2007 (Fig. 2). This drought was then followed in 2007 by one of the UK's wettest summers on record. In July 2007, the median flow at the Lower Hafren gauging station was $0.33 \mathrm{~m}^{3} \mathrm{~s}^{-1}$, almost 5 times higher than the long-term median flow experienced in July of $0.07 \mathrm{~m}^{3} \mathrm{~s}^{-1}$ (Environment Agency, 2007; Marsh, 2007; Marsh et al., 2007).

\subsection{Data resources}

There are two discharge gauging stations within the Hafren catchment which are located at the outflows from the upper and lower subcatchments (Fig. 1 and Table 1). Flows at the Lower Hafren flume have been recorded since 1976, with weekly chemical sampling beginning in 1983. Chemical sampling commenced at the Upper Hafren in 1990, at the upper boundary of the Hafren forest, but flows have only been recorded at this site since 2005 (Neal et al., 2010). Flows for the Upper Hafren site, for the period between 1990 and 2005, were estimated using the flows recorded at the Lower Hafren gauging station, as a strong linear correlation was identified between the flows at both stations 
$\left(U_{\mathrm{Haf}}=0.0152( \pm 0.0001)+L_{\mathrm{Haf}} \times 0.3468( \pm 0.0002) ;\right.$

$r^{2}=0.97, p<0.001, N=200152$ ) (Neal et al., 2010). Water quality samples were collected directly upstream of the flow gauging station in the Lower Hafren (Fig. 1). In the Upper Hafren, due to difficulties in accessing the river from the flume location, water quality samples were collected approximately $150 \mathrm{~m}$ upstream of the flume, above the Hafren forest edge. The two monitoring points are located approximately $2.5 \mathrm{~km}$ apart (Fig. 1).

In addition to the flow and streamwater chemistry data, hourly near-surface $(2 \mathrm{~m})$ air temperature, incoming solar radiation and rainfall volumes were recorded at the Carreg Wen AWS since 1976. Weekly rainfall and cloud water chemistry data are also available beginning in 1983 and 1990, respectively, and 7-hourly rainfall chemistry data are available between 2007 and 2009 (Table 1). Streamwater temperature measurements were made as part of the long-term monitoring scheme, but not the high-frequency monitoring scheme. Hourly air temperature recorded at the Carreg Wen AWS was therefore used as a surrogate for streamwater temperature, at both sites, to facilitate an assessment of the relationship between $\mathrm{NO}_{3}$ and temperature in the high-frequency time series.

\section{Methods}

\subsection{Data collection}

The long-term catchment monitoring was undertaken by collecting weekly grab samples, usually on the same day of each week, and then returning them to the laboratory for analysis. The same sampling route was followed on each site visit with the Lower Hafren sample collected first and the Upper Hafren sample approximately $1 \mathrm{~h}$ later (Brandt et al., 2004). The high-frequency monitoring scheme employed Xian automatic samplers within the field, at the same locations as the long-term monitoring points. The samplers were run on a 24 bottle programme, collecting 500 $\mathrm{ml}$ samples at $7 \mathrm{~h}$ intervals. The sample bottles were changed weekly and, as with the long-term monitoring, returned to the laboratory for processing (Neal et al., 2012).

All water quality samples were analysed for a wide range of chemical determinands including the major ions, nutrients, trace elements, $\mathrm{pH}$, alkalinity and conductivity. For the purpose of $\mathrm{N}$ analysis, under the long-term monitoring programme the weekly samples were filtered in the field using a $47 \mathrm{~mm} \mathrm{GF} / \mathrm{C}$ glass fibre filter into pre-cleaned glass bottles (chromic acid leached and distilled/deionised water), that were rinsed with the filtered water sample prior to sample storage. For the high-frequency monitoring programme, samples were filtered in the laboratory using a PALL Lifesciences AcroCap filter with a $0.45 \mu \mathrm{m}$ Supor ${ }^{\circledR}$ membrane pre-cleaned with distilled/deionised water and rinsed with filtered sample before storage. For both monitoring programmes sample $\mathrm{NO}_{3}$ and nitrite $\left(\mathrm{NO}_{2}\right)$ concentrations were determined by ion chromatography using the ICS-2000 system; ammonium $\left(\mathrm{NH}_{4}\right)$ concentrations were determined colorimetrically using a Seal discrete analyser; and total dissolved N (TDN) concentrations were determined by thermal oxidation and chemiluminescence with detection using the Shimadzu TNM-1 analyser. The accuracy of the determinations were evaluated using materials supplied by the Aquacheck LGC Interlaboratory Proficiency Testing Scheme. Dissolved organic nitrogen (DON) was determined by the standard approach of calculating the difference between the TDN concentration and the dissolved inorganic N (DIN) concentration (Eq. 1) (Graeber et al., 2012):

$\mathrm{DON}=\mathrm{TDN}-\mathrm{DIN}=\mathrm{TDN}-\left(\mathrm{NO}_{3}+\mathrm{NO}_{2}+\mathrm{NH}_{4}\right)$

Please see the supplementary data accompanying Neal et al. (2013c) for further details of the sampling procedure and analysis methodology. The complete, freely accessible long-term and high-frequency data sets are accessible via the Natural Environment Research Council (NERC) Environmental Information Data Centre (EIDC) (Neal et al., 2013a, b).

\subsection{Data pre-processing}

All the data sets used include periods of missing data. Within the long-term monitoring programme there were occasional times when sample collection was not done. These were the weeks preceding and following Christmas, a three-month period caused by restricted site access during the 2001 Foot and Mouth disease outbreak and rare occasions when heavy snowfall prevented site access (Cooper, 2004; Neal et al., 2003). During the high-frequency monitoring programme, samples were collected at $7 \mathrm{~h}$ intervals whenever possible, however occasionally samples could not be taken due to monitoring equipment malfunction. The time-series analysis techniques used here are designed to cope with data which include missing values and therefore infilling of missing values was not done. In all cases the raw observed time series have been analysed; no smoothing, averaging or infilling has taken place.

\subsection{Time-series decomposition}

All $\mathrm{NO}_{3}$ time series were investigated using standard exploratory data analysis techniques such as time-series plots, calculation of summary statistics, distribution analysis, and correlation and linear regression analysis. Time series of the difference in concentration between the lower and upper monitoring points were also used to investigate the $\mathrm{NO}_{3}$ dynamics along the river continuum, Eq. (2):

$C_{\mathrm{d}_{i}}=C_{\mathrm{L}_{i}}-C_{\mathrm{U}_{i}}$

where $C_{\mathrm{d}}$ is the difference in concentration between the Upper Hafren $\left(C_{\mathrm{U}}\right)$ and Lower Hafren, $\left(C_{\mathrm{L}}\right)$ at time $i$. 

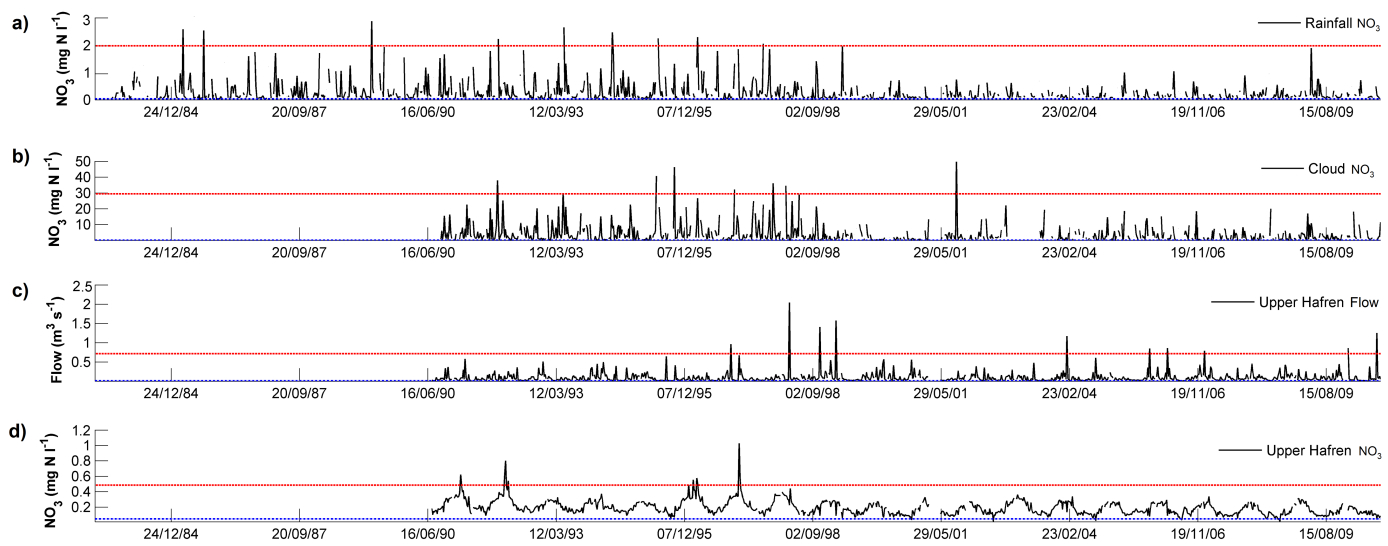

e)
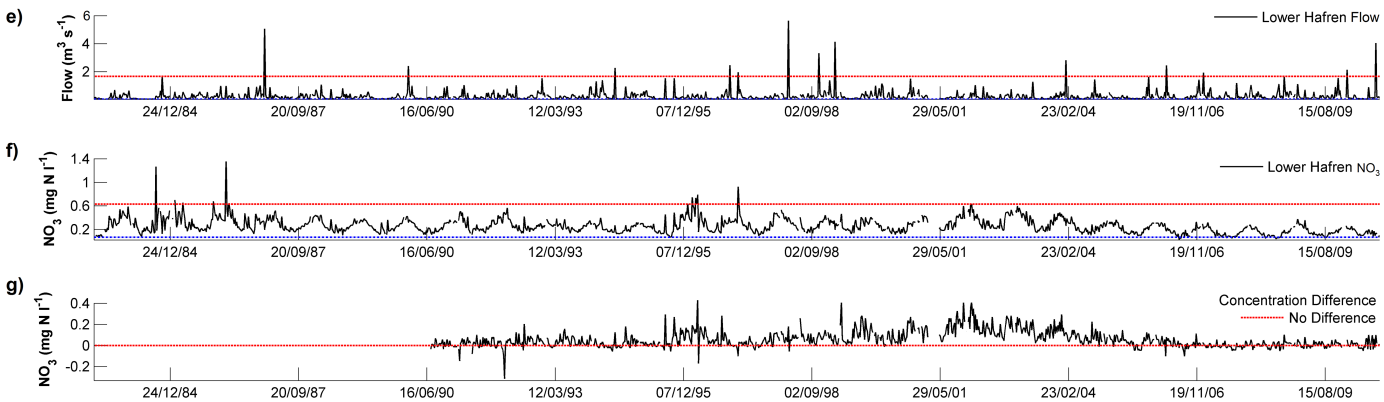

Fig. 3. Long-term $\mathrm{NO}_{3}$ and flow time series recorded within the Plynlimon catchment, mid-Wales. The red line and the blue line on plots (a-f) represent the 99th and 1st percentile of the time series, respectively. Concentration difference plot, (g), is based on the Lower Hafren $\mathrm{NO}_{3}$ concentration minus the concentration recorded at the Upper Hafren for each time step.

The concentration difference time series were analysed to determine if the median concentration difference was statistically different from zero, for the complete time series and for baseflow and stormflow time-series subsets where stormflows are defined as those flows greater than the 90th percentile flow and baseflows are those less than the 10th percentile.

The MATLAB ${ }^{\circledR}$-compatible CAPTAIN Toolbox, developed at Lancaster University for non-stationary time-series analysis, was used to explore the data sets (MathWorks, 2009; Young et al., 2007). The $\mathrm{NO}_{3}$ time series were analysed to assess long-term trends, seasonality and shorter-term cyclical signals. This analysis was undertaken using dynamic harmonic regression (DHR) analysis (Ciavatta and Pastres, 2011; Keery et al., 2007; Taylor et al., 2007; Young, 1998; Young et al., 1999; 2007). The method is described in detail by Taylor et al. (2007), Young (1998) and Young et al. (1999) and as such only a brief outline of the technique is provided below.

DHR is a special case of the unobserved component model, which decomposes an observed time series into its component parts (Halliday et al., 2012; Pedregal and Trapero, 2007; Taylor et al., 2007; Young et al., 1999, 2007):

$y_{t}=T_{t}+S_{t}+C_{t}+e_{t}$ $y_{t}$ is the observed time series; $T_{\mathrm{t}}$ is the trend; $S_{t}$ seasonal component; $C_{t}$ is a sustained cyclical component with a period separate from the seasonal component; and $e_{t}$ is an "irregular" component, defined in Eq. (3) as a random sequence from a Normal distribution with zero mean, and variance $\sigma^{2}$. To allow for non-stationarity in the time series, $y_{t}$, the parameters of Eq. (3) are defined as non-stationary stochastic variables (Young et al., 1999).

The trend, $T_{t}$, was defined using an integrated random walk (IRW) model (Taylor et al., 2007; Young et al., 2007). An IRW is a special case of the generalised random walk (GRW) in which the parameters $\alpha=\beta=\gamma=1$ and $\delta=$ 0 , and has been demonstrated to be useful for extracting smoothed trends from non-stationary long-duration time series, Eq. (4) (Ciavatta and Pastres, 2011; Young et al., 2007):

$T_{t}=\left(\begin{array}{ll}1 & 0\end{array}\right)\left(\begin{array}{l}x_{1 t} \\ x_{2 t}\end{array}\right)$

$$
\left(\begin{array}{l}
x_{1 t} \\
x_{2 t}
\end{array}\right)=\left(\begin{array}{ll}
\alpha & \beta \\
0 & \gamma
\end{array}\right)\left(\begin{array}{l}
x_{1 t-1} \\
x_{2 t-1}
\end{array}\right)+\left(\begin{array}{l}
\delta \\
1
\end{array}\right) \eta_{t-1}
$$

$T_{t}$ is the identified trend, consisting of the first state $x_{1 t}$; $x_{2 t}$ the second state, is the slope of the trend; and $\eta_{t-1}$ is a zero mean, serially uncorrelated white noise variable (Young 

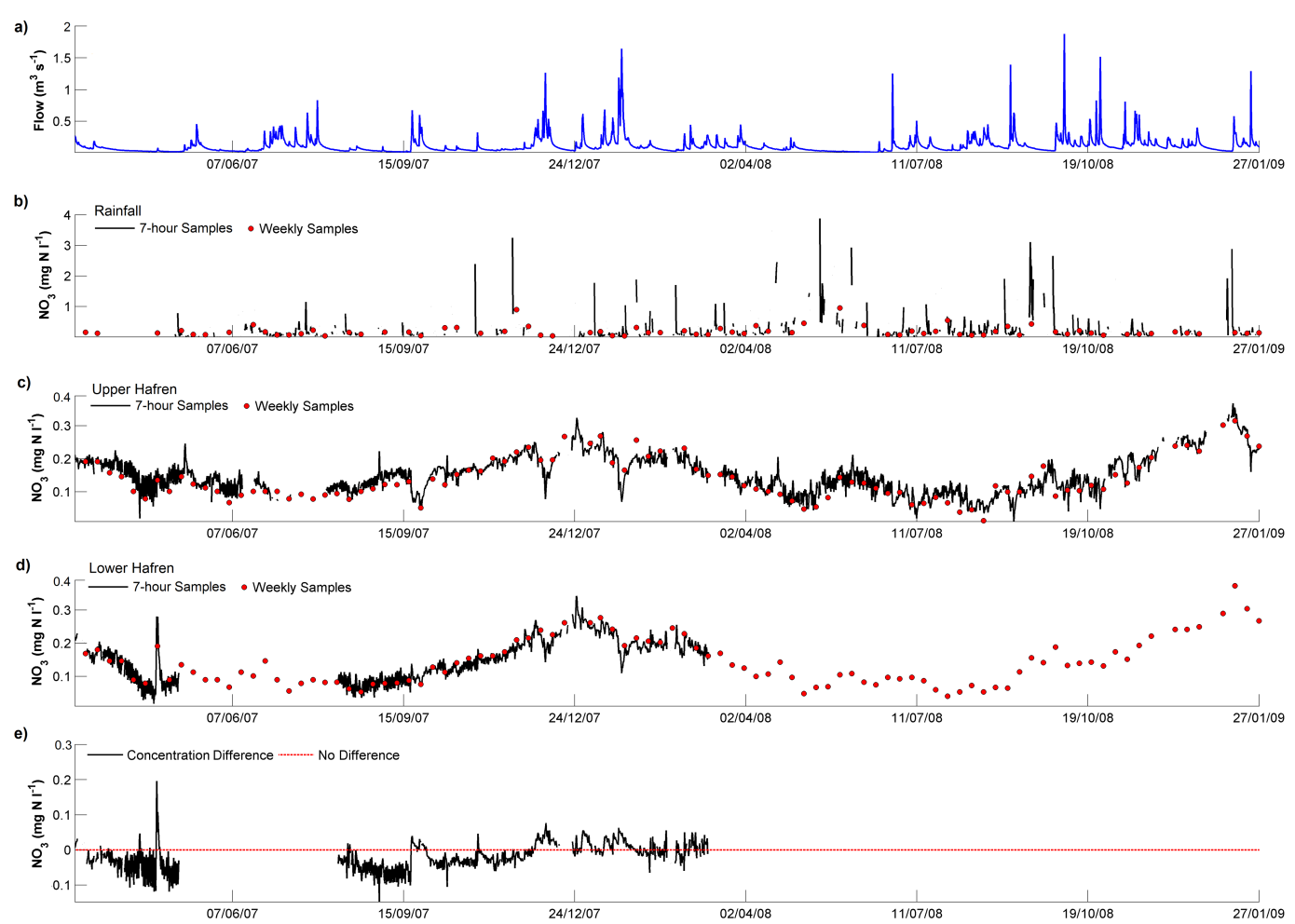

Fig. 4. High-frequency $\mathrm{NO}_{3}$ time series recorded within the Plynlimon catchment mid-Wales ( $7 \mathrm{~h}$ samples), with the long-term weekly monitoring samples overlain. Concentration difference plot, (a) is based on the Lower Hafren $\mathrm{NO}_{3}$ concentration minus the concentration recorded at the Upper Hafren for each time step.

et al., 2007). The trend was defined as statistically significant if the corresponding values of the slope parameter, $x_{2 t}$, were different from 0 , i.e. no change in the slope of the trend line, at a confidence level of 95\%, Eq. (4) (Becker et al., 2006; Ciavatta and Pastres, 2011).

The periodic components, $S_{t}$ and $C_{t}$, were defined as (Taylor et al., 2007; Young et al., 2007):

$\sum_{i=1}^{R}\left\{a_{i . t} \cos \left(w_{i} t\right)+b_{i, t} \sin \left(w_{i} t\right)\right\}$

$a_{i . t}$ and $b_{i . t}$ are stochastic time-varying parameters, which define the phase and amplitude of the seasonal/cyclic component, and were modelled as GRW processes. As these parameters can vary with time, this allowed for non-stationarity within the seasonal and short-term dynamics (Chappell and Tych, 2012). $w_{i}, i=1,2, \ldots, R$, are the fundamental and harmonic frequencies associated with the periodicity in the observed time series chosen by reference to the spectral properties of the series. For the long-term $\mathrm{NO}_{3}$ time series the only periodicities identified were associated with the period 52, which corresponded directly to an annual cycle under the weekly sampling regime. The trend component, $T_{t}$, and periodic components, $S_{t}$ and $C_{t}$, can be modelled simultaneously by the inclusion of a frequency of zero in the DHR analysis. This reduced Eq. (5) to $a_{i . t}$, which is modelled as an IRW process, as outlined above.

Under the $7 \mathrm{~h}$ sampling regime, 24 samples were collected per week, and within each week every hour of the day was sampled once (Neal et al., 2012). Accurately interpreting the diurnal dynamics from this 7-hourly data is complex because the data do not contain sufficient information to fully characterise the dynamics at this frequency. For example, if the $\mathrm{NO}_{3}$ signal exhibits a single peak diurnal cycle, as identified in other catchments (Nimick et al., 2011), under the 7-hourly regime the diurnal cycle peak and minimum will only be captured once a week and on different days (Halliday et al., 2012). DHR analysis was therefore used to model the expected diurnal cycle based on the information contained in the 7-hourly data. This was achieved using an hourly time series as input to the DHR analysis. This hourly time series was based on the 7-hourly data with the 6 time steps between each recorded sample assigned the MATLAB missing value code $(\mathrm{NaN})$. The 7-hourly data were not interpolated.

High-frequency monitoring was only undertaken for one year at the Lower Hafren monitoring point, between March 2007 and March 2008, and, due to sampling equipment failure, samples were not collected between late May and July 2007. The diurnal cycle analysis was therefore restricted to a subset of data, which allowed for the direct comparison 

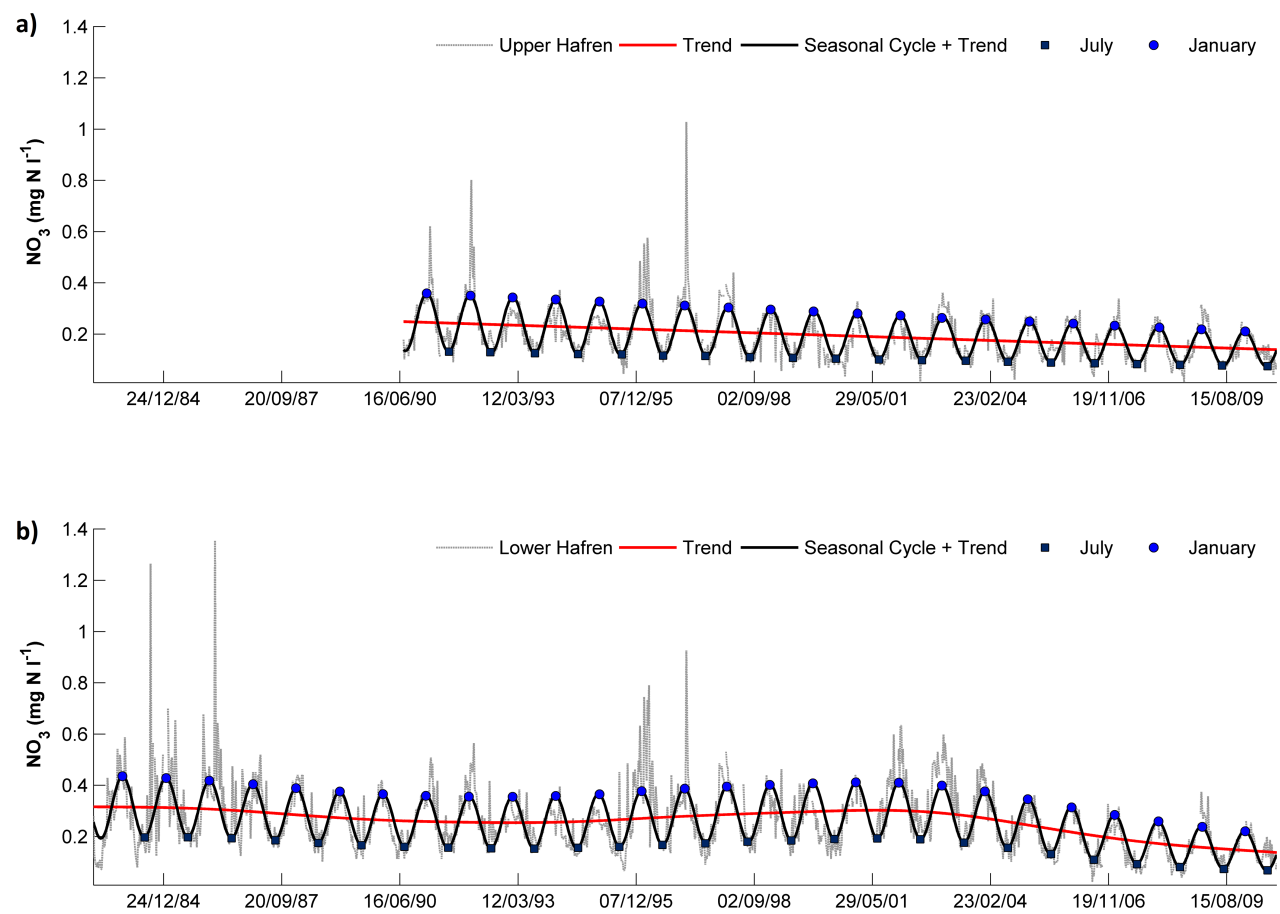

Fig. 5. Long-term $\mathrm{NO}_{3}$ trends and seasonality within the Plynlimon $\mathrm{NO}_{3}$ time series: (a) Upper Hafren and (b) Lower Hafren. Trends and seasonal cycles have been established through DHR analysis of the low-frequency time series using the CAPTAIN toolbox.

of dynamics at the upstream and downstream sites and limited the analysis to the spring and early summer when diurnal $\mathrm{NO}_{3}$ dynamics were most evident (Fig. 4; Nimick et al., 2011):

$$
\begin{aligned}
& \text { - 06/03/2007 19:00 GMT - 06/05/2007 11:00 GMT (62 } \\
& \text { days; referred to hereafter as Spring 2007). }
\end{aligned}
$$

The monitoring project was extended in the Upper Hafren until January 2009. Therefore, the diurnal cycle analysis was also undertaken on the same time period in 2008 , to facilitate an examination of how the diurnal $\mathrm{NO}_{3}$ dynamics varied between the two monitoring years:

$$
\begin{aligned}
& \text { - 06/03/2007 20:00 GMT - 06/05/2007 05:00 GMT (62 } \\
& \text { days; referred to hereafter as Spring 2008). }
\end{aligned}
$$

Under DHR, parameter optimisation was undertaken in the frequency domain, and used the spectral properties of the model, to optimise the parameters such that the logarithm of the model spectrum fits the logarithm of the empirical pseudo-spectrum of the raw time series in a least squares sense (Young et al., 1999; Keery et al., 2007; Young et al., 2007). The model parameters were estimated recursively using the Kalman filter and the fixed interval smoother. The recursive nature of this procedure allows for the handling of missing values so the pre-processed data can be analysed directly (Chappell and Tych, 2012; Romanowicz et al., 2006).

\section{Results}

Within the Hafren catchment, $\mathrm{NO}_{3}$ was the dominant form of streamwater $\mathrm{N}$, accounting for approximately $52 \%$ of the TDN; with $\mathrm{NO}_{2}$ accounting for less than $1 \%, \mathrm{NH}_{4}$ for approximately $10 \%$ and DON approximately $37 \%$ (based on the long-term annual average concentrations recorded under the weekly monitoring programme). Seasonal variability in the dominance of different $\mathrm{N}$ fractions was observed (Chapman et al., 2001). In the winter months, $\mathrm{NO}_{3}$ accounted for approximately $76 \%$ of the TDN between December and February at both sites. Between June and August, DON became more important, accounting for approximately $51 \%$ of the TDN.

Detailed analysis of the $\mathrm{N}$ dynamics of the Hafren stream was restricted to $\mathrm{NO}_{3}$. DON measurements were limited in both the long-term and high-frequency data sets and although high-frequency variability was visible in the observations, this appeared dominated by flow event responses with no identifiable, regular, cyclical pattern. In this upland N-limited system most $\mathrm{NH}_{4}$ is retained by plant uptake and chemical absorption (Peterson et al., 2001), and, as with DON there was no identifiable, regular, cyclical diurnal pattern within the high-frequency $\mathrm{NH}_{4}$ time series. 
Table 2. Summary statistics for the Plynlimon $\mathrm{NO}_{3}$ time series $\left(\mathrm{mg} \mathrm{NL}^{-1}\right)$ : all statistics were based on the complete $\mathrm{NO}_{3}$ record for each site, and Spring 2007 statistics are based on high-frequency data.

\begin{tabular}{lrrrr|rrr|r|r}
\hline \multirow{2}{*}{ Summary statistics } & \multicolumn{4}{c}{ Long-term } & \multicolumn{2}{c}{ High-frequency } & \multicolumn{2}{c}{ Spring 2007 } \\
\cline { 2 - 11 } & Upper & Lower & Rainfall & Cloud & Upper & Lower & Rainfall & Upper & Lower \\
\hline No. data points & 1009 & 1376 & 1031 & 793 & 2056 & 896 & 842 & 201 & 189 \\
\hline Minimum & 0.01 & 0.02 & $<0.01$ & 0.05 & 0.01 & 0.02 & 0.01 & 0.02 & 0.02 \\
Maximum & 1.03 & 1.35 & 2.89 & 49.68 & 0.37 & 0.34 & 3.88 & 0.23 & 0.28 \\
Range & 1.02 & 1.33 & 2.89 & 49.63 & 0.36 & 0.33 & 3.88 & 0.21 & 0.26 \\
\hline 3rd Quartile & 0.25 & 0.33 & 0.30 & 4.52 & 0.19 & 0.20 & 0.24 & 0.19 & 0.17 \\
1st Quartile & 0.12 & 0.17 & 0.09 & 0.76 & 0.11 & 0.10 & 0.07 & 0.14 & 0.08 \\
Interquartile range & 0.12 & 0.16 & 0.21 & 3.76 & 0.08 & 0.10 & 0.17 & 0.05 & 0.09 \\
\hline Mean & 0.19 & 0.26 & 0.28 & 4.01 & 0.15 & 0.15 & 0.26 & 0.16 & 0.12 \\
Median & 0.17 & 0.24 & 0.15 & 1.93 & 0.15 & 0.16 & 0.12 & 0.17 & 0.12 \\
\hline Stormflow mean & 0.19 & 0.31 & - & - & 0.13 & 0.19 & - & 0.19 & 0.19 \\
Baseflow mean & 0.15 & 0.16 & - & - & 0.14 & 0.08 & - & 0.15 & 0.06 \\
Flow weighted mean & 0.19 & 0.28 & - & - & 0.12 & 0.13 & - & 0.16 & 0.13 \\
\hline 99th Percentile & 0.49 & 0.63 & 1.98 & 29.42 & 0.30 & 0.28 & 2.39 & 0.21 & 0.26 \\
1st Percentile & 0.05 & 0.07 & 0.03 & 0.17 & 0.05 & 0.04 & 0.02 & 0.06 & 0.03 \\
\hline Variance & 0.01 & 0.02 & 0.14 & 33.50 & 0.00 & 0.00 & 0.19 & 0.00 & 0.00 \\
Standard deviation & 0.09 & 0.12 & 0.37 & 5.79 & 0.06 & 0.06 & 0.44 & 0.04 & 0.05 \\
Coefficient of variation & 48 & 48 & 132 & 144 & 37 & 40 & 169 & 23 & 43 \\
\hline
\end{tabular}

\subsection{Long-term catchment $\mathrm{NO}_{3}$ dynamics}

\subsection{1 $\mathrm{NO}_{3}$ trends}

Streamwater $\mathrm{NO}_{3}$ concentrations in the Hafren were low, $<1 \mathrm{mg} \mathrm{NL}{ }^{-1}$, (Figs. 3 and 4; Table 2) compared to concentrations of up to $14 \mathrm{mg} \mathrm{N} \mathrm{L}^{-1}$ reported within some agricultural European catchments (Sutton et al., 2011), but higher than some more pristine areas (the Upper Hafren is about the 38th percentile in the survey by Sudduth et al., 2013). Significant trends were identified within the long-term streamwater $\mathrm{NO}_{3}$ time series at both monitoring locations (Fig. 5). In the Upper Hafren there was a decreasing long-term trend, with mean annual concentration decreasing from $0.26 \mathrm{mg} \mathrm{NL}^{-1}$ (1991) to $0.14 \mathrm{mg} \mathrm{N} \mathrm{L}^{-1}$ (2010; Fig. 5a). In the Lower Hafren, the overall $\mathrm{NO}_{3}$ trend was a decline, with a change in mean annual concentration from 0.31 to $0.15 \mathrm{mg} \mathrm{N} \mathrm{L}^{-1}$ (1984-2010), however the extracted underlying trend showed an increase between 1993 and 2001 (Fig. 5b).

There were no significant trends in the catchment flow rates, rainfall volumes or cloud water deposition volumes over the study period. However, analysis of the inorganic $\mathrm{N}$ deposition $\left(\mathrm{NO}_{3}+\mathrm{NH}_{4}\right)$ at the Carreg Wen AWS revealed a marked shift in $\mathrm{N}$ deposition dynamics over the period of record. Non-significant increasing trends were observed in inorganic $\mathrm{N}$ concentrations in the rainfall and cloud water between the start of the records in 1983 and
1990, respectively, and 1997, with mean annual rainfall concentrations increasing from 0.62 to $0.89 \mathrm{mg} \mathrm{N} \mathrm{L}^{-1}$ and cloud water concentrations from 9.18 to $10.81 \mathrm{mg} \mathrm{N} \mathrm{L}^{-1}$. This was then followed by non-significant declining trend between 1998 and 2010, with mean annual concentrations falling to 0.37 and $6.22 \mathrm{mg} \mathrm{N} \mathrm{L}^{-1}$ in the rainfall and cloud water, respectively, by 2010. The marked reductions in rainfall and cloud water $\mathrm{N}$ concentrations after 1997 (Fig. 3a and b), are possibly caused by decreased atmospheric deposition associated with the closure of Pembroke Power Station (RWE npower, 2012), but may also be related to changes in weather patterns.

Streamwater temperature increased over the study period, from an annual mean of 7.2 and $6.9^{\circ} \mathrm{C}$ at the Upper and Lower Hafren, respectively, in 1991, to annual means of 8.9 and $8.7^{\circ} \mathrm{C}$ in 2010 (Fig. 6d). Part of this increase may have been driven by a move towards later sampling times over the course of the study period. At both sites the average annual sample time changed by $1 \mathrm{~h}$, from 09:00 to 10:00 GMT at the Lower Hafren and from 10:00 to 11:00 GMT at the Upper Hafren between 1990 and 2010, with a marked step change in 1999. Over this time the mean streamwater temperature difference was $0.5^{\circ} \mathrm{C}$ between 09:00 and 10:00 GMT and $0.4^{\circ} \mathrm{C}$ between 10:00 and 11:00 GMT. As the observed increase in streamwater temperature is greater than the change that would have resulted purely from changing the sampling time, this suggests that the increasing trend in streamwater temperature is real. 
Table 3. Spearman's rank correlation coefficients $(\rho)$ between $\mathrm{NO}_{3}$ and a selection of other determinands recorded at the Upper and Lower Hafren over various time periods (-: data unavailable).

\begin{tabular}{llll|ll}
\hline Determinand & \multicolumn{2}{l|}{ Upper Hafren } & & & Lower Hafren \\
\cline { 2 - 6 } & Long-term & Spring 2007 & Spring 2008 & Long-term & Spring 2007 \\
\hline Flow & $0.19^{* * *}$ & $0.71^{* * *}$ & 0.06 & $0.46^{* * *}$ & $0.87^{* * *}$ \\
pH & $-0.28^{* * *}$ & $-0.69^{* * *}$ & $-0.24^{* *}$ & $-0.59^{* * *}$ & $-0.83^{* * *}$ \\
Alkalinity & $-0.40^{* * *}$ & $-0.65^{* * *}$ & -0.14 & $-0.60^{* * *}$ & $-0.81^{* * *}$ \\
Conductivity & $0.37^{* * *}$ & - & - & $0.53^{* * *}$ & - \\
Calcium & -0.07 & $-0.58^{* * *}$ & -0.07 & $-0.10^{* * *}$ & $-0.52^{* * *}$ \\
Magnesium & $0.24^{* * *}$ & $-0.43^{* * *}$ & 0.07 & $0.28^{* * *}$ & 0.05 \\
Aluminium & 0.03 & $0.67^{* * *}$ & 0.01 & $0.56^{* * *}$ & $0.82^{* * *}$ \\
Dissolved organic carbon & $-0.33^{* * *}$ & $0.58^{* * *}$ & -0.18 & $-0.11^{* * *}$ & $0.39^{* * *}$ \\
Chloride & $0.34^{* * *}$ & - & $0.55^{* * *}$ & $0.32^{* * *}$ & - \\
Sodium & $0.20^{* * *}$ & $-0.42^{* * *}$ & - & $0.23^{* * *}$ & $0.40^{* * *}$ \\
Manganese & $0.40^{* * *}$ & $0.71^{* * *}$ & $0.24^{* *}$ & $0.66^{* * *}$ & $0.86^{* * *}$ \\
Cobalt & $0.41^{* * *}$ & $0.75^{* * *}$ & $0.72^{* * *}$ & $0.67^{* * *}$ & $0.85^{* * *}$ \\
Arsenic & $-0.59^{* * *}$ & $-0.68^{* * *}$ & $0.58^{* * *}$ & $-0.34^{* * *}$ & $-0.70^{* * *}$ \\
Silicon & $0.10^{* *}$ & - & $-0.49^{* * *}$ & $-0.24^{* * *}$ & - \\
Cerium & -0.08 & $0.63^{* * *}$ & - & $0.28^{* * *}$ & $0.77^{* * *}$ \\
Praseodymium & -0.09 & $0.68^{* * *}$ & -0.07 & $0.23^{* * *}$ & $0.77^{* * *}$ \\
Streamwater temperature & $-0.77^{* * *}$ & - & - & $-0.60^{* * *}$ & - \\
Air temperatura & $-0.72^{* * *}$ & $-0.78^{* * *}$ & $-0.56^{* * *}$ & $-0.61^{* * *}$ & $-0.58^{* * *}$ \\
Solar radiation & $-0.50^{\mathrm{a}}$ & $-0.43^{* * *}$ & $-0.33^{* * *}$ & $-0.50^{* * *}$ & -0.07 \\
\hline
\end{tabular}

*** Correlation statistically significant at $p<0.001 ;{ }^{* *} p<0.01 ;{ }^{*} p<0.05 ;{ }^{\text {a }}$ Recorded at the Carreg Wen Automatic Weather Station.

Table 4. The median difference in concentration between the Lower and Upper monitoring points for the complete time series and the baseflow and stormflow periods ${ }^{\mathrm{a}}$.

\begin{tabular}{|c|c|c|c|}
\hline $\begin{array}{l}\text { Monitoring } \\
\text { programme }\end{array}$ & $\begin{array}{l}\text { Complete } \\
\text { data sets }\end{array}$ & Baseflow & Stormflow \\
\hline High-frequency & $-0.02 * * *(865)$ & $-0.06^{* * *(105)}$ & $0.03^{* * *(86)}$ \\
\hline Long-term & $0.03^{* * *(1005)}$ & $0.00 *(85)$ & $0.07 * * *(107)$ \\
\hline Long-term $(2007)^{b}$ & $-0.01 *(50)$ & $-0.01^{(6)}$ & $0.02^{(6)}$ \\
\hline
\end{tabular}

a Results of the one-sample Wilcoxon signed rank test: significantly different from zero at $p<0.001^{* * *} ; p<0.01^{* *} ; p<0.05^{*}$ (number of samples in brackets). ${ }^{b}$ Annual concentration difference for the year 2007 based on the long-term monitoring.

\subsubsection{Upstream - downstream dynamics}

The long-term concentration difference time series showed that overall $\mathrm{NO}_{3}$ concentrations were higher at the Lower Hafren monitoring point, with a median concentration of $0.24 \mathrm{mg} \mathrm{NL}^{-1}$ compared to $0.17 \mathrm{mg} \mathrm{NL}^{-1}$ (Fig. 3g). The difference between median concentrations at both sites was statistically significant (Mann-Whitney $\mathrm{U}$ test, $p<0.001$; Table 2; Fig. 7). The distributions of the $\mathrm{NO}_{3}$ concentrations at both sites were also statistically different, with the range in $\mathrm{NO}_{3}$ concentrations greater at the Lower Hafren site, $1.33 \mathrm{mg} \mathrm{N} \mathrm{L}^{-1}$, than at the Upper Hafren, $1.02 \mathrm{mg} \mathrm{NL}^{-1}$ (Two-sample Kolmogorov-Smirnov test: $p<0.001$; Fig. 7).

There was a strong positive correlation between the $\mathrm{NO}_{3}$ concentrations in the Upper and Lower Hafren in the long-term time series (Fig. 7c):

$$
\begin{aligned}
& L_{\mathrm{HafW}}=0.949 \times\left(U_{\mathrm{HafW}}\right)+0.065 \\
& r^{2}=0.56 ; p<0.001 ; N=1006
\end{aligned}
$$

$\mathrm{NO}_{3}$ concentrations in the Hafren showed significant correlations with a number of other determinands recorded as part of the long-term monitoring scheme (Table 3). In general the relationships were largely consistent between the upstream and downstream monitoring points, with positive correlations with atmospherically derived determinands such as chloride $(\mathrm{Cl})$ and sodium $(\mathrm{Na})$ and negative correlations with streamwater temperature and alkalinity (Table 3 ).

At Plynlimon, stormflow streamwater is acidic with elevated aluminium (Al) and dissolved organic carbon (DOC) concentrations and decreased calcium (Ca) and silicon $(\mathrm{Si})$ concentrations, indicating the dominance of acidic upper soil water; these relationships are reversed under baseflow conditions (Soulsby and Reynolds, 1993; Halliday et al., 2012; Neal et al., 2011; 2012). Under stormflow conditions, the difference in $\mathrm{NO}_{3}$ concentration between the lower and upper monitoring sites doubled from 0.03 to $0.07 \mathrm{mg} \mathrm{N} \mathrm{L}^{-1}$ (Table 4). This observation suggests that under stormflow conditions water from the upper soil horizons, delivered from the forested lower reaches of the catchment, has elevated $\mathrm{NO}_{3}$ concentrations, and provides a source of $\mathrm{NO}_{3}$ to the streamwater which is not present in the soil water derived from the purely moorland upper reaches. This conclusion is supported by the positive correlation 
Table 5. Seasonality analysis: the results of the DHR seasonal cycle extracted from the long-term streamwater $\mathrm{NO}_{3}$, flow and temperature time series at both sites and from the rainfall $\mathrm{NO}_{3}$, air temperature and incoming solar radiation time series recorded at Carreg Wen Automatic Weather Station.

\begin{tabular}{|c|c|c|c|c|c|c|}
\hline Site & Determinand & $\begin{array}{l}\text { Dominant } \\
\text { phase } \\
\text { peak }\end{array}$ & $\begin{array}{l}\text { Dominant } \\
\text { phase } \\
\text { minima }\end{array}$ & $\begin{array}{l}\text { Maximum } \\
\text { annual } \\
\text { amplitude }\end{array}$ & $\begin{array}{l}\text { Average } \\
\text { strength* }^{*}\end{array}$ & $\begin{array}{l}\text { Seasonality } \\
\text { amplitude } \\
\text { trend }\end{array}$ \\
\hline \multirow[t]{3}{*}{$\begin{array}{l}\text { Upper } \\
\text { Hafren }\end{array}$} & $\mathrm{NO}_{3}$ & Jan & Jul & $0.23 \mathrm{mg} \mathrm{NL}^{-1}$ & $62 \%$ & $\begin{array}{l}\text { Decreasing throughout } \\
\text { the period of record }\end{array}$ \\
\hline & Flow & Dec & Jun & $0.11 \mathrm{~m}^{3} \mathrm{~s}^{-1}$ & $17 \%$ & Variable \\
\hline & $\begin{array}{l}\text { Streamwater } \\
\text { Temp. }\end{array}$ & Jul & Jan & $7.05^{\circ} \mathrm{C}$ & $66 \%$ & $\begin{array}{l}\text { Decreasing amplitude until } \\
1999 \text { and increasing since }\end{array}$ \\
\hline \multirow[t]{3}{*}{$\begin{array}{l}\text { Lower } \\
\text { Hafren }\end{array}$} & $\mathrm{NO}_{3}$ & Jan & Jul & $0.24 \mathrm{mg} \mathrm{NL}^{-1}$ & $57 \%$ & $\begin{array}{l}\text { Overall decrease over the } \\
\text { period of record, with } \\
\text { a period of increasing ampli- } \\
\text { tude between } 1993 \text { and } 1998\end{array}$ \\
\hline & Flow & Jan & Jul & $0.28 \mathrm{~m}^{3} \mathrm{~s}^{-1}$ & $18 \%$ & Variable \\
\hline & $\begin{array}{l}\text { Streamwater } \\
\text { Temp. }\end{array}$ & Aug & Feb & $8.27^{\circ} \mathrm{C}$ & $59 \%$ & $\begin{array}{l}\text { Increasing throughout } \\
\text { the period of record }\end{array}$ \\
\hline \multirow[t]{2}{*}{$\begin{array}{l}\text { Carreg } \\
\text { Wen }\end{array}$} & Air Temp. & Jul & Jan & $13.2^{\circ} \mathrm{C}$ & $55 \%$ & $\begin{array}{l}\text { Decreasing between } 1984 \text { and } \\
1998 \text { and increasing since }\end{array}$ \\
\hline & $\begin{array}{l}\text { Solar } \\
\text { Radiation }\end{array}$ & Jun & Dec & $444 \mathrm{~W} \mathrm{~m}^{-2}$ & $55 \%$ & $\begin{array}{l}\text { Decreasing between } 1984 \text { and } \\
1996 \text { and increasing since }\end{array}$ \\
\hline
\end{tabular}

* The average strength of the seasonal cycle has been calculated as the average percentage of annual variability (the range of concentrations recorded) explained by the maximum amplitude of the identified annual cycle.

between $\mathrm{Al}$ and $\mathrm{NO}_{3}$ in the Lower Hafren which is not present at the Upper Hafren site (Table 3), Al being a marker for soil water at Plynlimon.

\subsection{Seasonal $\mathrm{NO}_{3}$ dynamics}

Strong seasonal signals dominated the streamwater $\mathrm{NO}_{3}$ time series at both the Upper and Lower Hafren, with a strong positive correlation between the mean monthly $\mathrm{NO}_{3}$ concentrations at both sites $(\rho=0.79 ; p<0.001$; Fig. 5 and Table 5). At both monitoring points, although there was slight variability in the exact phase of the seasonality, the overall pattern was consistent with peak $\mathrm{NO}_{3}$ concentrations occurring in the winter months, between January and February, and the minimum concentrations occurring in the summer months, between July and August. The amplitude of the seasonality, at both sites, closely followed the overall trend in the streamwater $\mathrm{NO}_{3}$ concentrations. In the Upper Hafren, the amplitude of the seasonal cycle decreased through the period of record, but the cycle was nonetheless very strong, accounting for on average $62 \%$ of the annual range in $\mathrm{NO}_{3}$ concentrations (Table 5). Overall, the amplitude of the Lower Hafren seasonal $\mathrm{NO}_{3}$ cycle also decreased over the study period, however periods of greater seasonal variability were observed between 1996 and 1998 and between 2001 and 2004 (Fig. 5).

A seasonal cycle could not be extracted from the rainfall volume or the cloud water deposition volumes. In addition, there was no extractable seasonal cycle in the catchment $\mathrm{N}$ inputs, in terms of rainfall or cloud water $\mathrm{NO}_{3}$ and $\mathrm{NH}_{4}$ concentrations. Strong seasonal cycles were observed within the flow, streamwater temperature and incoming solar radiation time series (Fig. 6). The flow seasonality exhibited a strong and consistent phase at both sites and was in phase with the $\mathrm{NO}_{3}$ seasonality, with peak flows in the winter and minimum flows in the summer. There was variability in the amplitude for the flow seasonality at both sites, with increasing amplitude associated with periods of extreme rainfall, such as the winter of 1998 (Fig. 3c and e). Streamwater temperature and solar radiation exhibited seasonality with the opposite phase to $\mathrm{NO}_{3}$, with peak streamwater temperatures and incoming solar radiation in the summer months, between June and August, and minimums in the winter months, between December and February (Fig. 6c, d). The identified seasonality was very strong for both determinands, contributing on average $60 \%$ to the annual variability (Table 5), and the cycle amplitudes were consistent throughout the study period. 


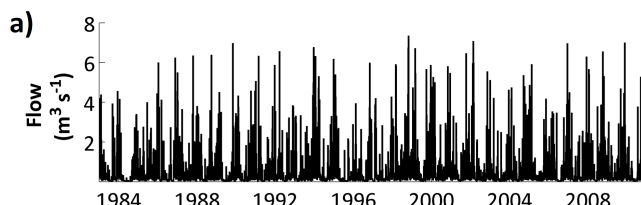

b)

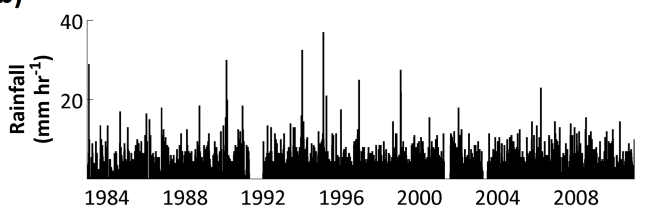

c)

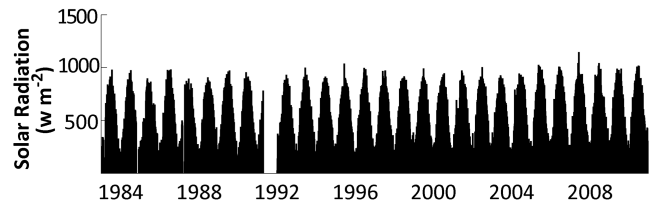

d)

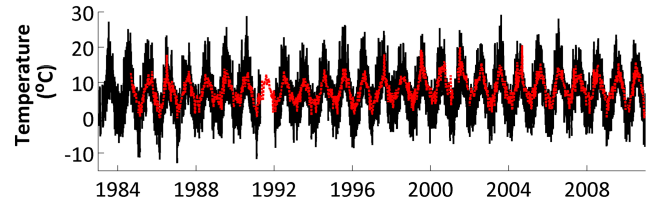

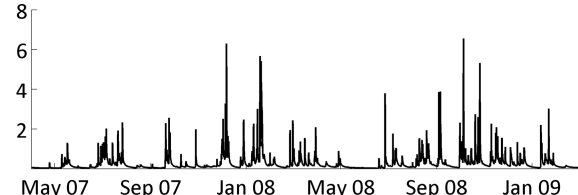
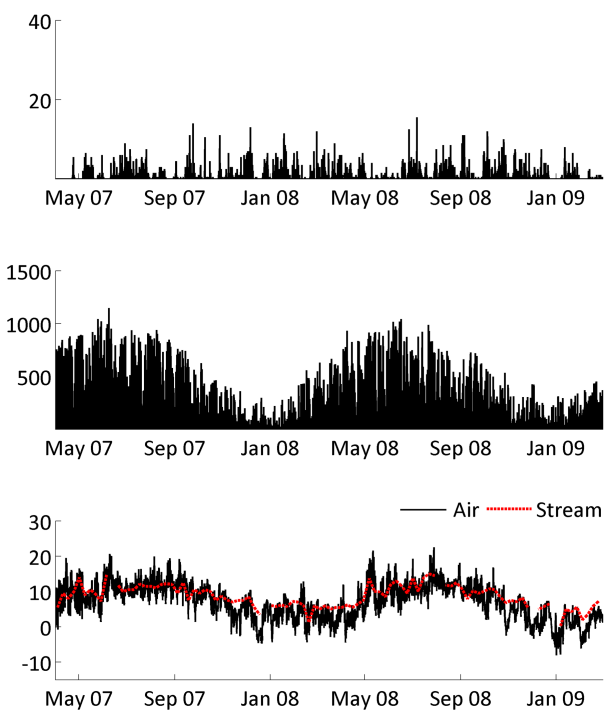

Fig. 6. Explanatory variables: the left-hand column displays the complete record (1983-2010) and the right-hand column the period of record covering the high-frequency study period: (a) hourly flow at Lower Hafren gauging station, (b) hourly rainfall at Carreg Wen Automatic Weather Station (CW-AWS), (c) hourly solar radiation at CW-AWS, and (d) hourly air temperature at CW-AWS and weekly streamwater temperature at the Lower Hafren monitoring point.

\subsection{Short-term variability in $\mathrm{NO}_{3}$ dynamics}

The high-frequency data revealed seasonal, event and diurnal variability in $\mathrm{NO}_{3}$ concentrations. Within the context of the long-term $\mathrm{NO}_{3}$ variability, both the Upper and Lower Hafren $\mathrm{NO}_{3}$ concentrations were in decline between 2007 and 2009 (Fig. 5). The seasonal pattern identified in the high-frequency data was consistent with that identified in the long-term monitoring data sets, with concentration peaks in the winter months and minimums in the summer months (Fig. 4).

The high-frequency concentration difference time series showed a slightly different pattern to the long-term data with $\mathrm{NO}_{3}$ concentrations higher at the Upper Hafren monitoring point than at the lower (Fig. 4e), with a difference in median concentration of $-0.02 \mathrm{mg} \mathrm{NL}^{-1}$, which more than triples under baseflow conditions to $-0.06 \mathrm{mg} \mathrm{NL}^{-1}$ (although small these differences were statistically different from zero; Table 4). The occurrence of higher $\mathrm{NO}_{3}$ concentrations at the upper monitoring point during 2007 can also be seen in the long-term monitoring data when annual changes in the concentration differences are analysed (Figs. 3g, 4e and Table 4). The difference between $\mathrm{NO}_{3}$ concentrations in the lower and Upper Hafren under stormflow conditions is the same in the high-frequency data as the long-term data, with elevated concentrations evident at the lower monitoring point. These results indicate that, despite the small differences under baseflow conditions, under stormflow conditions the flows derived from the forested catchment still had a higher $\mathrm{NO}_{3}$ concentrations than those coming from the moorland dominated catchment.

Excluding Spring 2007, at the Upper Hafren significant dilutions in $\mathrm{NO}_{3}$ concentration were observed during high flow events, with concentrations dropping by over $0.15 \mathrm{mg}$ $\mathrm{NL}^{-1}$ from baseflow concentrations (Fig. 4c). In the Lower Hafren, despite the flow rates being almost 3 times higher than in the Upper Hafren, the level of dilution in response to high flow events was greatly diminished (Fig. 4d). These event dynamics support the observations made in the long-term data sets that the soil water derived from moorland upper reaches of the Hafren catchment was depleted in $\mathrm{NO}_{3}$ in comparison to the soil water delivered from the forested lower reaches.

A strong degree of diurnal variability was visible in high-frequency $\mathrm{NO}_{3}$ time series at both the Upper and Lower Hafren (Fig. 4). The diurnal dynamics exhibited a seasonal pattern with dynamics strongest in the spring and summer months, when $\mathrm{NO}_{3}$ concentrations were at their lowest (Figs. 8 and 9). The modelled diurnal dynamics provide a first means of investigating the complexity present in the high-frequency $\mathrm{NO}_{3}$ data. 
Table 6. Diurnal cycle analysis: the results of the diurnal cycle extracted from the high-frequency $\mathrm{NO}_{3}$ time series using dynamic harmonic regression. Diurnal cycling within the air temperature and solar radiation time series was also investigated.

\begin{tabular}{|c|c|c|c|c|c|c|c|}
\hline $\begin{array}{l}\text { Monitoring } \\
\text { point }\end{array}$ & Determinand & $\begin{array}{l}\text { Spring } \\
\text { period }\end{array}$ & $\begin{array}{c}\text { Dominant } \\
\text { peak time } \\
(\mathrm{GMT})\end{array}$ & $\begin{array}{l}\text { Dominant } \\
\text { minimum time } \\
(\mathrm{GMT})\end{array}$ & $\begin{array}{l}\text { Maximum } \\
\text { diurnal } \\
\text { cycle } \\
\text { amplitude }\end{array}$ & $\begin{array}{c}\text { Average } \\
\text { diurnal } \\
\text { cycle } \\
\text { amplitude }\end{array}$ & $\begin{array}{c}\text { Percentage } \\
\text { of } \\
\text { diurnal } \\
\text { variability* }\end{array}$ \\
\hline \multirow[t]{2}{*}{ Upper Hafren } & \multirow[t]{2}{*}{$\mathrm{NO}_{3}\left(\mathrm{mg} \mathrm{NL}^{-1}\right)$} & 2007 & 02:00-03:00 & $14: 00-15: 00$ & 0.07 & 0.04 & $80 \%$ \\
\hline & & 2008 & 00:00-01:00 & $12: 00-13: 00$ & 0.03 & 0.02 & $58 \%$ \\
\hline Lower Hafren & $\mathrm{NO}_{3}\left(\mathrm{mg} \mathrm{NL}^{-1}\right)$ & 2007 & 09:00 & 21:00 & 0.05 & 0.04 & $76 \%$ \\
\hline \multirow[t]{4}{*}{ Carreg Wen } & \multirow[t]{2}{*}{ Air Temp. $\left({ }^{\circ} \mathrm{C}\right)$} & 2007 & $14: 00-15: 00$ & 02:00-03:00 & 12.7 & 6.07 & $83 \%$ \\
\hline & & 2008 & $14: 00-15: 00$ & $23: 00-01: 00$ & 9.12 & 3.79 & $79 \%$ \\
\hline & \multirow[t]{2}{*}{$\begin{array}{l}\text { Solar Radiation } \\
\left(\mathrm{W} \mathrm{m}^{-2}\right)\end{array}$} & 2007 & $12: 00$ & $\begin{array}{c}\text { Zero between } \\
\text { 18:00-05:00 }\end{array}$ & 456 & 285 & $42 \%$ \\
\hline & & 2008 & 11:00-13:00 & $\begin{array}{c}\text { Zero between } \\
\text { 18:00-05:00 }\end{array}$ & 469 & 205 & $40 \%$ \\
\hline
\end{tabular}

* The percentage of diurnal variability has been calculated as the average percentage of daily variability (i.e. the range of concentrations recorded on a given day) explained by the maximum amplitude of the identified diurnal cycle on the same day.

\subsubsection{Diurnal dynamics: Spring 2007}

During Spring 2007, streamwater $\mathrm{NO}_{3}$ concentrations were higher at the Upper Hafren monitoring point than the lower, with a median difference of $-0.03 \mathrm{mg} \mathrm{NL}^{-1}$ (Fig. 8 and Table 2). Streamwater $\mathrm{NO}_{3}$ concentrations in the Upper Hafren were significantly correlated with a range of determinands (Table 3), exhibiting negative correlations with variables such as air temperature, solar radiation, $\mathrm{pH}$ and $\mathrm{Ca}$ and positive correlations with flow, DOC and Al. The Lower Hafren exhibited very similar correlations, but with a weaker correlation with air temperature and no significant relationship with solar radiation (Table 3). These relationships differ from the relationships identified in the long-term record, where DOC was found to be negatively correlated with $\mathrm{NO}_{3}$ at both sites and both $\mathrm{Ca}$ and flow exhibited much weaker correlations with $\mathrm{NO}_{3}$ (Table 3).

A single-peak diurnal $\mathrm{NO}_{3}$ cycle was observed at both monitoring points. In the Upper Hafren, the modelled diurnal cycle phase was consistent, with peak $\mathrm{NO}_{3}$ concentrations between 02:00 and 03:00 GMT and minimum concentrations between 14:00 and 15:00 GMT (Fig. 8 and Table 6). The amplitude of the cycle was very small at the beginning of the period, $<0.01 \mathrm{mg} \mathrm{NL}^{-1}$, and apart from a smaller amplitude at the end of April, during increased flow, increased throughout the period to $0.07 \mathrm{mg} \mathrm{N} \mathrm{L}^{-1}$ (median standard error $=0.004)$. In the Lower Hafren, the diurnal cycle phase was less consistent, with the timing of peak and minimum concentrations varying throughout the period. At the start of the period, peak concentrations occurred at 04:00 GMT, $1 \mathrm{~h}$ later than peak concentrations occurred at the Upper Hafren, but by the end of the period they were occurring at 09:00 GMT, $7 \mathrm{~h}$ later than the Upper Hafren (Fig. 8; Table 6). The amplitude of the cycle again strengthened throughout, but the maximal amplitude reached was only $0.05 \mathrm{mg} \mathrm{NL}^{-1}$ (median standard error $=0.005$ ). The high $\mathrm{NO}_{3}$ peaks observed between the 23 and 24 of April in the Lower Hafren time series, associated with the delivery of $\mathrm{NO}_{3}$ from the catchment during the high-flow event (Fig. 8b), do not significantly affect the modelled diurnal cycling, with the diurnal variability retained under these peaks.

Diurnal cycling was not identified in rainfall volume, $\mathrm{N}$ deposition, or flow rates at either site. However, as expected strong diurnal cycles were of course identified in the hourly air temperature and solar radiation time series (Table 6). For air temperature, peak temperatures occurred at approximately 14:00 GMT and minimum temperatures at approximately 02:00 GMT, the opposite phase to the Upper Hafren diurnal $\mathrm{NO}_{3}$ cycle. A positive relationship was evident between amplitude of the temperature and $\mathrm{NO}_{3}$ diurnal cycles, indicating that as the diurnal variation in temperature increased, so too did the variation in $\mathrm{NO}_{3}$ concentration. For solar radiation, diurnal peaks occurred at 12:00 GMT followed by diurnal minimums during the night, when solar radiation is zero. This was also the opposite phase to the Upper Hafren $\mathrm{NO}_{3}$ cycle, but minimum $\mathrm{NO}_{3}$ concentrations lagged peak solar radiation by, on average, two hours.

\subsubsection{Diurnal dynamics: Spring 2008}

The modelled diurnal $\mathrm{NO}_{3}$ cycle for the Upper Hafren in Spring 2008 period was weaker and more variable than 

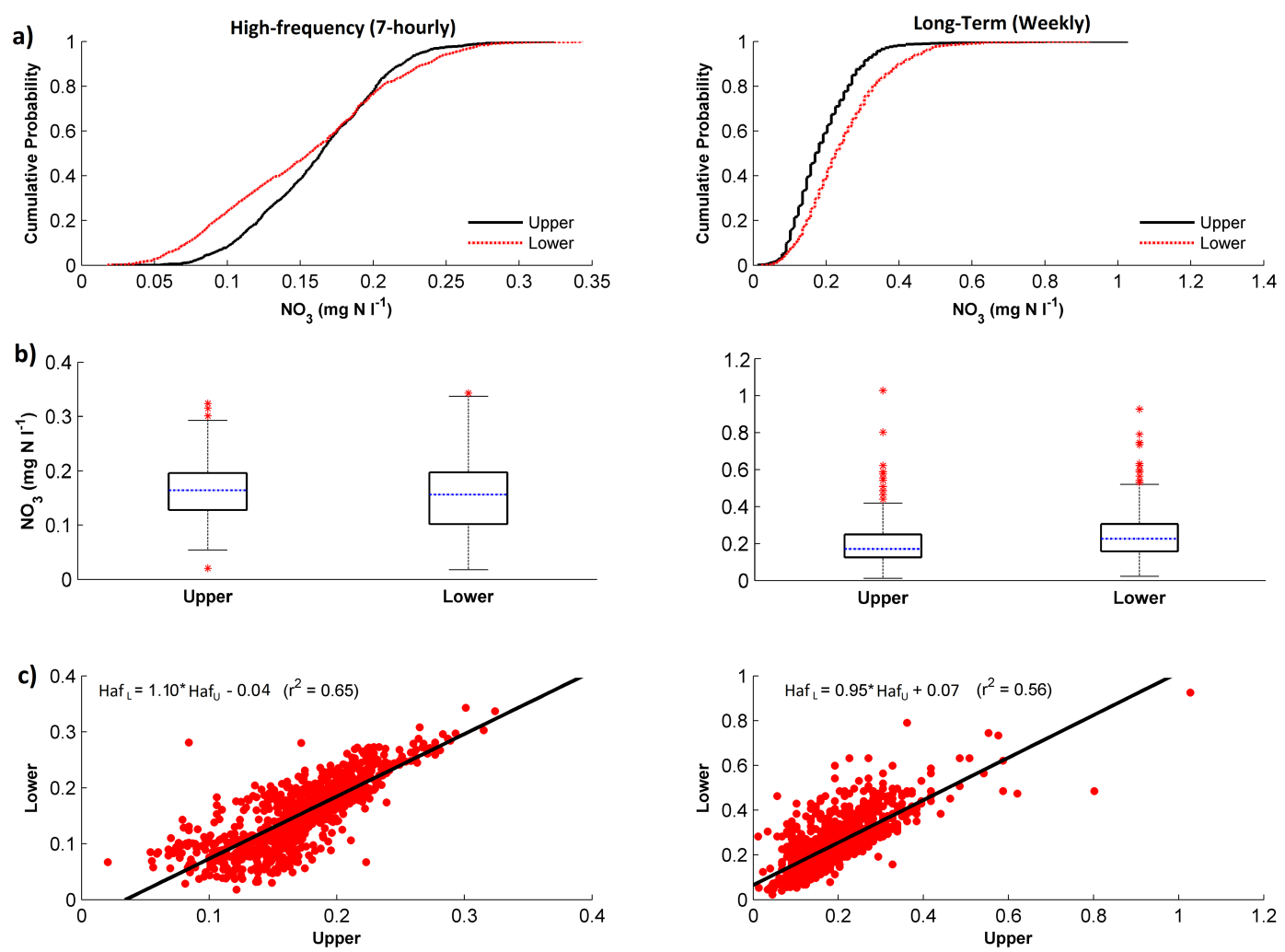

Fig. 7. $\mathrm{NO}_{3}$ time-series distribution plots. Plots show the common period of record for each data set long-term 1990-2010, and highfrequency March 2007 to March 2008. The left hand displays the high-frequency data and the right the long-term data: (a) distribution plots; (b) box plots, where the box is the inter-quartile range (IRQ), the line across the box is the median, the whiskers are $\pm 1.5^{*} \mathrm{IQR}$, and extremes, denoted ${ }^{*}$, are any points outside this range; and (c) relationships between the $\mathrm{NO}_{3}$ concentrations at the upper and lower catchment monitoring locations.

the cycling identified in Spring 2007 (Fig. 9; Table 6). In Spring 2008, the maximum amplitude of the diurnal $\mathrm{NO}_{3}$ cycle in the Upper Hafren was only $0.03 \mathrm{mg} \mathrm{NL}^{-1}$ compared to $0.07 \mathrm{mg} \mathrm{N} \mathrm{L}^{-1}$ in Spring 2007. In addition, the timing of peak concentrations varied between 23:00 and 03:00 GMT in Spring 2008, compared to between 02:00 and 03:00 GMT in Spring 2007. In Spring 2008, $\mathrm{NO}_{3}$ also exhibited different relationships with other determinands than observed in Spring 2007. Principally, where in 2007 a strong positive correlation was found between flow and $\mathrm{NO}_{3}$ ( $\rho=0.71, p<0.0001)$, no relationship was found in Spring 2008 (Table 3). Furthermore, no significant correlations were found between $\mathrm{NO}_{3}$ and $\mathrm{Ca}, \mathrm{Mg}, \mathrm{Al}$ or DOC, which in Spring 2007 had strong significant correlations with $\mathrm{NO}_{3}$ (Table 3).

As in Spring 2007, no diurnal dynamics were identified in rainfall volumes, $\mathrm{N}$ deposition, or flow time series. Air temperature was more variable in Spring 2008, with the timing of peak diurnal temperatures varying between 08:00 and 17:00 GMT. In addition the amplitude of the diurnal variation was smaller, on average only $3.5^{\circ} \mathrm{C}$ compared to $6.0^{\circ} \mathrm{C}$ in 2007 . The solar radiation diurnal cycle was very similar to that observed in Spring 2007.

\section{Discussion}

\subsection{Drivers of long-term $\mathrm{NO}_{3}$ dynamics}

\subsection{1 $\mathrm{NO}_{3}$ trends}

The main long-term trend was the decline in streamwater $\mathrm{NO}_{3}$ concentrations over the study period at both sites (Sect. 4.1), with a decline of $46 \%$ in the Upper Hafren (1991-2010) and 51\% in the Lower Hafren (1984-2010). The most likely explanation for the long-term $\mathrm{NO}_{3}$ decline was lower atmospheric $\mathrm{N}$ inputs, supplemented by increased $\mathrm{N}$ uptake driven by increasing temperatures, and perhaps also linked to stimulation of hyporheic denitrification by increased DOC availability.

Historic work within the Plynlimon catchment has related declining trends in streamwater $\mathrm{NO}_{3}$ to declining atmospheric $\mathrm{N}$ deposition, associated with emission control legislation (Neal et al., 2001). Atmospheric N deposition is the only significant $\mathrm{N}$ input to the $\mathrm{N}$-limited Hafren system, with the majority of deposition occurring as wet deposition (wet $\mathrm{NO}_{3}$ and $\mathrm{NH}_{4}$ deposition accounted for $67 \%$ of the total $\mathrm{N}$ deposition at Plynlimon between 2007 
a)

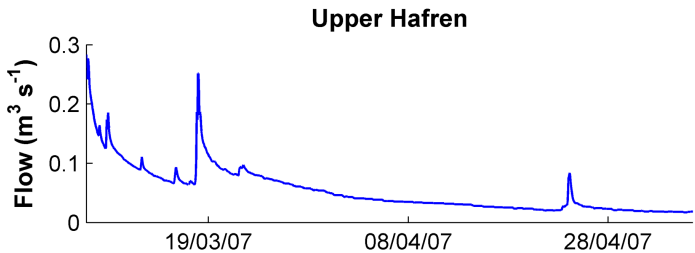

b)

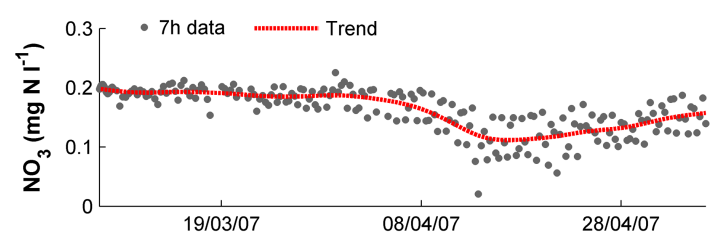

c)

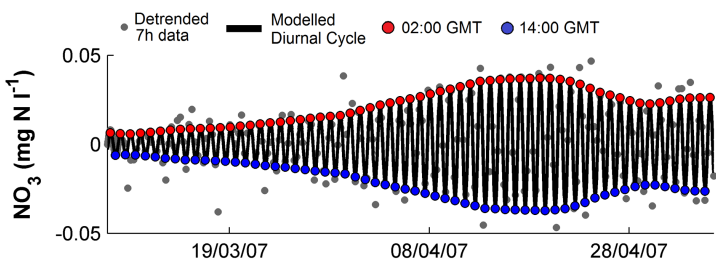

d)

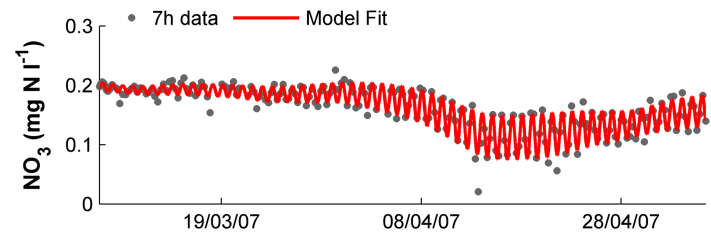

e)

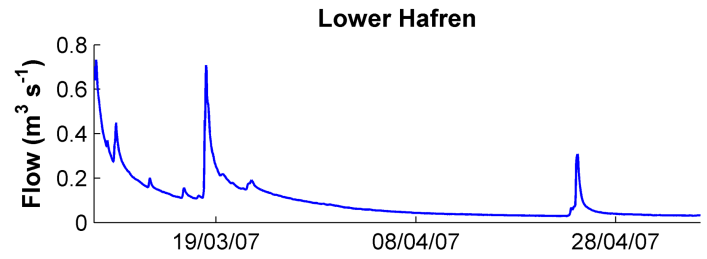

f)

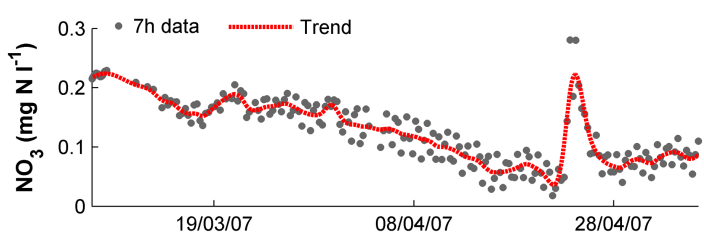

g)

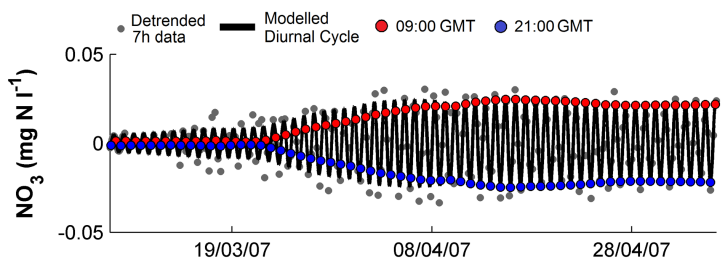

h)

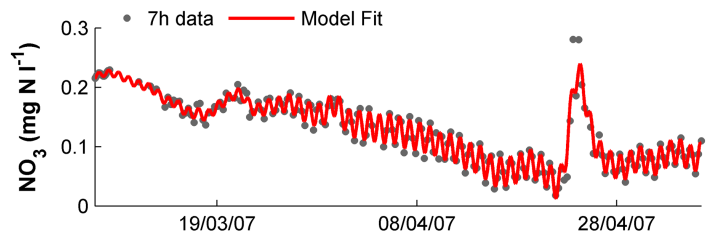

Fig. 8. Statistically modelled diurnal cycling in Spring 2007 (March to May 2007), of the Hafren $\mathrm{NO}_{3}$ time series, using dynamic harmonic regression. On the left-hand side are the Upper Hafren data and on the right-hand side the Lower Hafren: (a) and (e) flow; (b) and (f) modelled trend, with observed data; (c) and (g) modelled diurnal cycle, with detrended data; and (d) and (h) model fit (trend + diurnal cycle), with observed data. Diurnal cycle plots show variations above and below the identified trend (zero).

and 2009: DEFRA, 2012). Although annual N deposition amounts are quite variable, the analysis demonstrated an increasing trend in rainfall and cloud water $\mathrm{NO}_{3}$ and $\mathrm{NH}_{4}$ concentrations up to 1997 , followed by a declining trend. Overall the timing of the decline in stream $\mathrm{NO}_{3}$ does not correlate with the timing of the decline in atmospheric $\mathrm{N}$ deposition, nor is there any evidence of a lagged effect; instead, streamwater $\mathrm{NO}_{3}$ concentrations decline steadily throughout the period of record, 1990-2010, in the Upper Hafren. This situation is similar to that observed in the NE USA (e.g. Bernal et al., 2012). Therefore, although reductions in atmospheric deposition will have affected the streamwater $\mathrm{NO}_{3}$ dynamics, additional factors may have also contributed to the declining trend.

Climate changes, such as increasing temperature, have also been linked to streamwater $\mathrm{NO}_{3}$ trends in other systems (e.g. Bernal et al., 2012). At Plynlimon, increasing streamwater temperatures will have promoted increased $\mathrm{NO}_{3}$ uptake by the diatom biofilms, bryophyte communities and cyanobacteria in the stream bed and hyporheic zone (Ledger and Hildrew, 2005; Frame, 2010; Kernan et al., 2010; Shilland et al., 2012). The significant strong negative correlation identified between streamwater $\mathrm{NO}_{3}$ and temperature (Table 3 ) and the temperature dependence of the seasonal and diurnal $\mathrm{NO}_{3}$ variation (see below) support this. Assuming an exponential relationship between temperature and the rates of biological processes and assuming that a $10^{\circ} \mathrm{C}$ increase in temperature doubles these rates (following the $Q_{10}$ model; Chapra, 1997, p. 40), the observed streamwater temperature change would increase uptake rates by approximately $12-16 \%$ over the study period. Therefore, although this alone is insufficient to explain the decline in streamwater $\mathrm{NO}_{3}$ concentrations, it likely will have played a contributory role in the long-term decline.

$\mathrm{NO}_{3}$ may also be removed from the system by other temperature-sensitive processes, such as denitrification. Although increased temperatures will have reduced oxygen supply slightly, denitrification in the Hafren flowing water is unlikely, as the river is still a highly oxygenated system (Environment Agency, 2009). However, denitrification in microsites in the hyporheic zone may have occurred, stimulated by increased DOC availability (e.g. Trimmer et 
al., 2012). Streamwater DOC concentrations have increased in the Hafren on the same timescale as $\mathrm{NO}_{3}$ has decreased (Halliday et al., 2012), and $\mathrm{NO}_{3}$ and DOC are significantly negatively correlated (Table 3). The factors controlling denitrification in flowing waters are not well understood (see e.g. Trimmer et al., 2012), and further work is required to quantify the role this mechanism has played in the long-term streamwater $\mathrm{NO}_{3}$ decline. Other hypotheses suggested elsewhere to account for declining $\mathrm{NO}_{3}$ concentrations such as an increase in $\mathrm{N}$ storage, associated with woody debris dams, and recovery from catchment disturbances (e.g. Bernhardt et al., 2005; Bernal et al., 2012) are not applicable in the Upper Hafren catchment where there are no trees and land use change has not occurred. In addition, although cyclic meteorological phenomena such as the North Atlantic Oscillation (NAO) may have a subtle effect through altering hydrological pathways (Monteith et al., 2000; Ness et al., 2004), the $\mathrm{NO}_{3}$ decline has continued through periods of both positive and negative NAO Index values.

\subsubsection{Upstream - downstream dynamics and forest effects}

In general, streamwater $\mathrm{NO}_{3}$ concentrations were higher at the Lower Hafren monitoring site than the upper (Fig. 3). This indicates that the forested lower reaches of the catchment were producing more $\mathrm{NO}_{3}$. Forest planting on wet moorlands in the UK, as at Plynlimon, is achieved by extensive ditch cutting, with the trees being planted on upturned soil between the ditches (e.g. Reynolds and Edwards, 1995). This, together with lower water fluxes under the trees due to interception loss, creates a drier soil which can lead to increased soil $\mathrm{N}$ mineralisation compared to the moorland. Enhanced N deposition to the trees is also a possibility (e.g. Chapman et al., 1999; Neal, 2002; Soulsby et al., 2002).

Between 1994 and 2003, streamwater $\mathrm{NO}_{3}$ concentrations increased at the Lower Hafren site, (Fig. 5), but not at the upper. This was likely linked to the clear felling of some forest blocks in the lower catchment (Neal et al., 2004b). Previous work within the Plynlimon catchment has demonstrated that clear felling results in large increases in streamwater $\mathrm{NO}_{3}$ concentrations and fluxes from the clear-felled block (Neal et al., 2003, 2004b, 2011, 2005; Reynolds and Edwards, 1995). After clear felling, the forest is re-planted, or, less usually, allowed to regenerate naturally. This creates a sink for $\mathrm{N}$ due to uptake by the actively growing trees. The Hafren Forest as a whole is a patchwork of mature forest, clear-felled areas and rapidly growing young forest, thus limiting the observed increases in stream $\mathrm{NO}_{3}$ due to clear felling. For instance, stream $\mathrm{NO}_{3}$ concentrations in clear-felled blocks at Plynlimon reached $4.3 \mathrm{mg} \mathrm{NL}^{-1}$ (Neal et al., 2004b), whereas the average increase in Fig. 5 is $<0.1 \mathrm{mg} \mathrm{NL}^{-1}$. Whether the upper or Lower Hafren has higher $\mathrm{NO}_{3}$ concentrations depends on the balance between clear-felled and actively growing areas. The main felling years in the catchment were 1981, 1986, 1988, and 1994-1998 (Neal et al., 2004b) and there has been no significant felling since 2004 . This pattern can be seen in Fig. 3. Nitrogen mineralisation after clear-cutting also explains why previous research did not identify a significant trend in the Hafren streamwater $\mathrm{NO}_{3}$ time series, as the period analysed only covered 1988 to 2000/2002, the period over which the main felling years occurred (Evans and Monteith, 2001; Wright et al., 2001). These contrasting findings also raise questions over whether the twenty-year time series used in this research are of a sufficient length to accurately identify nutrient trends (Bernal et al., 2012). This question can only be answered by the continuation of monitoring in the Hafren system.

\subsection{Controls on seasonal $\mathrm{NO}_{3}$ dynamics}

The seasonality in $\mathrm{NO}_{3}$ time series was consistent in both the Upper and Lower Hafren, with concentration peaks in the winter and minimums in the summer. Over the long-term study period, the phase of the seasonal $\mathrm{NO}_{3}$ cycle was consistent, with annual minimums identified to occur in July for $90 \%$ of the record. This annual minimum in July coincides with annual minimums in streamflow, and with annual maximums in solar radiation and temperature. Solar radiation and temperature both affect biological activity, including $\mathrm{N}$ uptake processes in both the catchment and the stream. These two possibilities cannot be distinguished as causes of seasonal variation from these data. The diurnal variation appears to be due to instream processes (see below). However, the amplitude of the seasonal $\mathrm{NO}_{3}$ variation is much greater than that of the diurnal variation (c. $0.2 \mathrm{mg}$ $\mathrm{NL}^{-1}$ compared to $0.02-0.04 \mathrm{mg} \mathrm{NL} \mathrm{NL}^{-1}$; Figs. 5 and 8 , Tables 5 and 6 ), whereas the amplitudes of the air temperature and solar radiation seasonal variations were only approximately double the observed diurnal variations (Tables 5 and 6). It seems likely therefore that instream processes alone cannot account for the seasonal variation, though they will make a contribution; for instance, studies in agricultural catchments tend to show higher instream $\mathrm{NO}_{3}$ removal rates in summer (Birgand et al., 2007). The catchment thus retains $\mathrm{NO}_{3}$ more efficiently in summer; it is noticeable in Fig. 5 that unusually high $\mathrm{NO}_{3}$ concentrations in the Upper Hafren occur exclusively in winter, though this is not so in the Lower Hafren during periods of clear-felling. The results imply that $\mathrm{N}$ uptake processes appear to dominate over $\mathrm{N}$ production processes such as soil organic matter mineralisation, which would also be expected to increase in summer due to higher temperatures.

Figure 5 also shows an effect that is hard to explain other than by a decline in atmospheric $\mathrm{N}$ deposition; in the Upper Hafren the annual maximum $\mathrm{NO}_{3}$ concentrations show a steady decline. These occur in winter when all the evidence suggests that biological uptake is small. 
Table 7. Partial correlation analysis - investigation of the $\mathrm{NO}_{3}$, temperature and solar radiation relationship in the Hafren catchment.

\begin{tabular}{llllll|lll|c}
\hline \multirow{2}{*}{ Determinand } & \multirow{2}{*}{ Effect eliminated } & \multicolumn{2}{c}{ Long-term } & \multicolumn{2}{c}{ High-frequency } & \multicolumn{2}{c}{ Spring 2007} & \multicolumn{2}{c}{ Spring 2008 } \\
\cline { 3 - 8 } & & Upper & Lower & Upper & Lower & Upper & Lower & Upper \\
\hline Temperature $^{\mathrm{a}}$ & Solar radiation & $-0.69^{* * *}$ & $-0.48^{* * *}$ & $-0.60^{* * *}$ & $-0.66^{* * *}$ & $-0.72^{* * *}$ & $-0.64^{* * *}$ & $-0.55^{* * *}$ \\
Solar radiation $^{\text {a }}$ & Temperature & $-0.17^{* * *}$ & $-0.32^{* * *}$ & $-0.11^{* * *}$ & 0.00 & -0.09 & $0.33^{* * *}$ & -0.15 \\
\hline
\end{tabular}

a Streamwater temperature for the long-term data; air temperature for the high-frequency data and spring periods. $* * *$ Correlation statistically significant at $p<0.001 ; * *$ $p<0.01 ;{ }^{*} p<0.05$.

a)

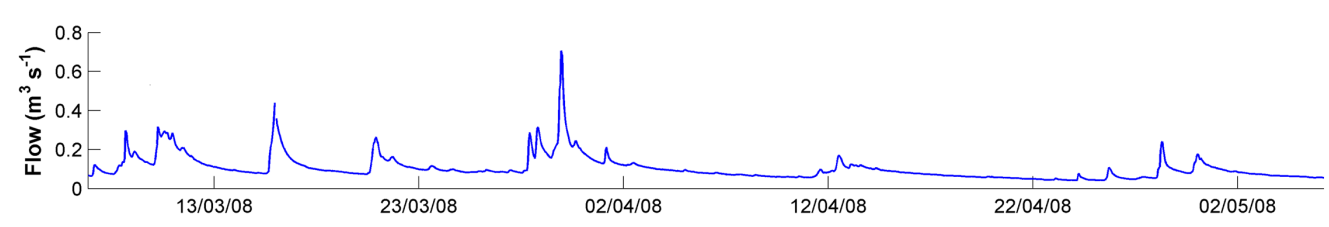

b)
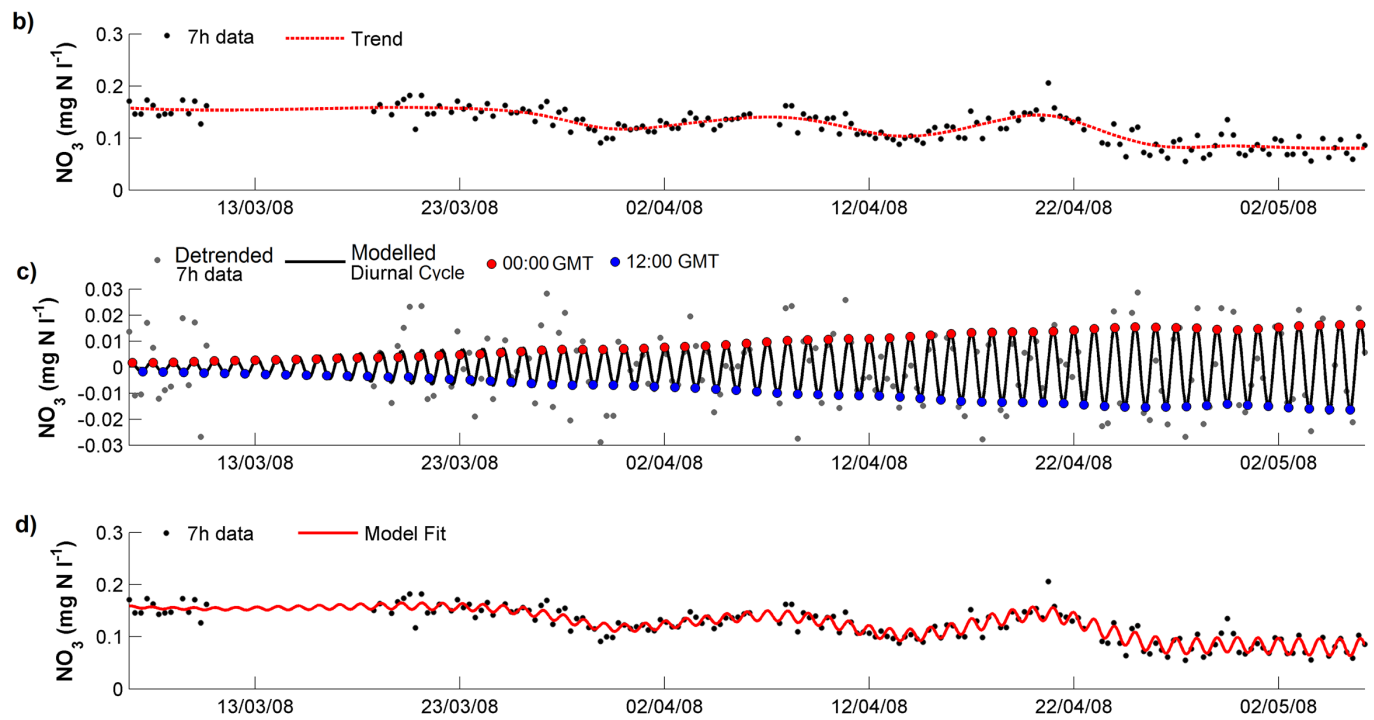

Fig. 9. Statistically modelled diurnal cycling in Spring 2008 (March to May 2008), of the Upper Hafren $\mathrm{NO}_{3}$ time series using dynamic harmonic regression: (a) flow, (b) modelled trend, with observed data, (c) modelled diurnal cycle, with detrended data and (d) model fit (trend + diurnal cycle), with observed data. Diurnal cycle plots show variations above and below the identified trend (zero).

\subsection{Controls on diurnal $\mathrm{NO}_{3}$ dynamics: Spring 2007}

Both the Upper and Lower Hafren show a single peak diurnal cycle in $\mathrm{NO}_{3}$ concentrations which is strongest in summer and declines in winter (Figs. 8 and 9; Halliday et al., 2012). In the Upper Hafren this cycle had a consistent phase controlled by instream $\mathrm{N}$ uptake processes, however in the Lower Hafren the cycling was more complex with a variable phase and smaller amplitude, as a result of signal advection and dispersion from the upstream site and changes in the catchment $\mathrm{NO}_{3}$ processing in the forested reaches (see below).

\subsubsection{Upper Hafren controls}

The regularity of the cycle phase at Upper Hafren is consistent with the hypothesis that instream processing is responsible for the observed diurnal dynamics (Halliday et al., 2012). If the diurnal cycling was being controlled by catchment processes outside of the stream, more variability in the phase and amplitude of the diurnal dynamics would be anticipated as the signal observed in the stream would be the composite signal from across the whole catchment. In addition, the cycling would be expected to vary with flow, whereas Fig. 8a and c show that phase remains independent of flow over a wide range of conditions.

Possible causes for the diurnal cycle include $\mathrm{N}$ uptake by stream organisms and denitrification, driven by diurnal cycles of temperature and light flux. Both of these correlate negatively with $\mathrm{NO}_{3}$ concentration (Table 3 ), but the negative correlation is stronger with temperature than solar radiation. Partial correlation analysis showed that in the long-term data sets, temperature and solar radiation had independent effects 
on $\mathrm{NO}_{3}$ concentration, but that temperature independent of solar radiation correlated better with $\mathrm{NO}_{3}$ concentration. In the high-frequency data sets, negative correlations with temperature alone remained high, but correlations with solar radiation independent of temperature were lower, and were not significant or even positive in the Lower Hafren (Table 7). Minimum $\mathrm{NO}_{3}$ concentrations coincided with maximum diurnal air temperatures and lagged maximum solar radiation by approximately 2 hours. This is consistent with findings in other studies where daily minimums in $\mathrm{NO}_{3}$ concentration lagged daily solar radiation maximums (Heffernan and Cohen, 2010). Lag effects were investigated with solar radiation but no improvement in correlation was found.

The correlation with solar radiation indicates a role for photosynthetic organisms in uptake, whereas the correlation with temperature could involve a variety of other organisms too. The Upper Hafren is a small oligotrophic stream which lacks significant macrophytes, and the stream bed substrate consists largely of boulders, pebbles and exposed bedrock (Newson and Harrison, 1978). The most likely photosynthetic assimilators are the diatom biofilms and bryophytes growing on pebbles and rocks in the stream bed (Fig. 1; see Sect. 2.1). Such biofilms are known to have strong $\mathrm{NO}_{3}$ absorbing capacities (e.g. Duff et al., 2008), and this would explain the strong diurnal cycles with daytime minimums. This is also supported by the seasonal pattern in the observed diurnal dynamics, with the amplitude of the diurnal cycle strongest in the spring and summer periods and dying away to nothing during in the winter.

The correlation between $\mathrm{NO}_{3}$ and temperature independent of solar radiation, suggests a possible role for non-photosynthetic organisms, perhaps in the deeper part of the hyporheic zone where uptake is not light-dependent (see review by Ranalli and Macalady, 2010). Denitrification or other removal processes in the hyporheic zone are a possibility (see Trimmer, 2012), even though this is a well-oxygenated system, but further research is required to determine the significance of this process to the diurnal streamwater $\mathrm{NO}_{3}$ dynamics.

\subsubsection{Lower Hafren controls}

The long-term records from the Hafren demonstrated that the streamwater temperature difference between the upstream and downstream monitoring sites rarely exceeded $2{ }^{\circ} \mathrm{C}$ $(<8 \%$ of the record). Therefore, changes in streamwater temperature along the river are unlikely to be critical in the differences observed in the diurnal system dynamics (Pattinson et al., 1998).

The change in the cycle phase between the upper and lower monitoring points fits with the hypothesis of advection of the $\mathrm{NO}_{3}$ signal from the Upper Hafren monitoring point along the river. Using the discharge velocity relationships determined by Newson and Harris (1978), the travel time between the Upper and Lower Hafren was estimated to be approximately $2 \mathrm{~h}$ under normal flow conditions, less than an hour under stormflow conditions and over $7 \mathrm{~h}$ under baseflow conditions. Although these calculations were only an approximation of the travel time, they do indicate that the changes in cycle phase between the upper and lower monitoring points were consistent with the advection of the signal down the river - for instance the peak occurs $7 \mathrm{~h}$ later in low flow conditions in Fig. 8. Significant negative correlations were identified between the difference in timing of the diurnal $\mathrm{NO}_{3}$ peaks between upper and lower monitoring point and the observed mean daily flow recorded at both sites $(\rho=-0.94 ; p<0.001 ; \mathrm{N}=60$, and $\rho=$ $-0.86 ; p<0.001 ; \mathrm{N}=60$, for the upper and lower flows, respectively). This result confirms that, as flow increases, the time required for signal advection downstream decreases.

The fact that the diurnal cycle at the Lower Hafren site appears to be dominated by the signal from the open moorland even though this is only about half the full catchment area (Fig. 1), shows that the forested area, which is a mixture of first- and second-generation forest, does not have a consistent diurnal cycle of its own. The amplitude of the diurnal $\mathrm{NO}_{3}$ cycling in the lower reaches is likely reduced by dispersion as a result of the increased flow magnitude and variability at this monitoring point (Spring 2007: $\mathrm{Haf}_{\mathrm{Low}}=$ $\left.2.507 \times\left(\mathrm{Haf}_{\mathrm{Up}}\right)-0.036 ; r^{2}=0.94 ; p<0.001 ; \mathrm{N}=5825\right)$.

Reduced light penetration to the stream through the forest canopy may also have limited photosynthetic $\mathrm{NO}_{3}$ uptake and the higher flows may have scoured the stream bed rock surfaces, removing the diatom biofilms and bryophytes responsible for the diurnal $\mathrm{NO}_{3}$ cycling at the Upper Hafren site (Fig. 1; Chapman et al., 1996; Dawson and Wilby, 2001; Dawson et al., 2001; Nimick et al., 2011; Rusjan et al., 2008; Rusjan and Mikos, 2010). The lower $\mathrm{NO}_{3}$ concentrations visible at low flow at the Lower Hafren site in the Spring 2007 period (Fig. 8) may also be due to $\mathrm{N}$ uptake by the growing forest as discussed above, or by faster $\mathrm{N}$ processing in the forested catchment streams. For instance, in Spring 2007 the mean DOC concentration in the streamwater was $1.5 \mathrm{mg} \mathrm{CL}^{-1}$ at the Lower Hafren compared to $1.0 \mathrm{mg} \mathrm{C} \mathrm{L}^{-1}$ at the Upper Hafren. Bernhardt and Likens (2002) showed that DOC enrichment in the stream draining Watershed 6 in the Hubbard Brook Experimental Forest New Hampshire, USA, stimulated microbial growth. The result also supports the hypothesis that the long-term decline in stream $\mathrm{NO}_{3}$ is influenced by the long-term increase in DOC concentrations.

\subsubsection{Significance of diurnal cycling}

It is interesting to consider the significance of the diurnal variation in $\mathrm{NO}_{3}$ concentrations compared to catchment $\mathrm{N}$ metabolism. If the diurnal amplitude on a particular day is taken as an estimate of $\mathrm{N}$ uptake (it may be an underestimate, because non-photosynthetic $\mathrm{N}$ uptake may still be occurring at the maximum amplitude), it is possible 
to estimate roughly how significant stream processing is in terms of catchment $\mathrm{N}$ metabolism. Method 1, as outlined by Heffernan and Cohen (2010), was used to calculate the average daily $\mathrm{NO}_{3}$ uptake over the first 14 days in April 2007. This approach uses the daily maximum $\mathrm{NO}_{3}$ concentrations at 03:00 GMT as a baseline to calculate the hourly $\mathrm{NO}_{3}$ deficiency attributed to autotrophic assimilation using Eq. (7).

$U_{\mathrm{NO}_{3}}=\frac{Q}{A} \sum_{t=0}^{24}\left(\left[\mathrm{NO}_{3}\right]_{\max (0)}-\left[\mathrm{NO}_{3}\right]_{t}\right)$

where $U_{\mathrm{NO}_{3}}$ is the uptake $\left(\mathrm{mg} \mathrm{N} \mathrm{m} \mathrm{N}^{-2} \mathrm{~d}^{-1}\right), Q$ is the average daily discharge $\left(\mathrm{L} \mathrm{h}^{-1}\right), A$ is the riverbed area $\left(\mathrm{m}^{2}\right)$, $\left[\mathrm{NO}_{3}\right]_{\max (0)}$ is the preceding $\left[\mathrm{NO}_{3}\right]_{\max }$ and $\left[\mathrm{NO}_{3}\right]_{t}$ is the $\mathrm{NO}_{3}$ concentration $\left(\mathrm{mg} \mathrm{NL} \mathrm{N}^{-1}\right.$ ) at time $t$. Over the first 14 days in April 2007 the average $\mathrm{NO}_{3}$ uptake rate was $115 \mathrm{mg} \mathrm{N} \mathrm{m}^{-2} \mathrm{~d}^{-1}$, assuming the Upper Hafren stream width is approximately $60 \mathrm{~cm}$ and its length $1.3 \mathrm{~km}$. This rate is comparable with values reported in other streams such as the Hubbard Brook Experimental forest and the Ichetucknee River in Florida (Bernhardt et al., 2002; Heffernan and Cohen, 2010). Referred to the Upper Hafren catchment area (122 ha) and extrapolated to a whole year, this amounts to only $0.27 \mathrm{~kg} \mathrm{Nha}^{-1} \mathrm{yr}^{-1}$, even though this is one of the periods of maximal uptake. This is much smaller than the annual $\mathrm{N}$ retention by the Hafren catchment as a whole of approximately $14 \mathrm{~kg} \mathrm{~N} \mathrm{ha}^{-1} \mathrm{yr}^{-1}$ (e.g. Curtis et al., 2005), demonstrating that the terrestrial catchment still retains most of the $\mathrm{N}$. The fate of the absorbed $\mathrm{N}$ is not known - it could be transferred higher in the food chain (e.g. to grazers on the biofilms), exported as particulate organic $\mathrm{N}$ or as gaseous $\mathrm{N}$ products, or retained in the sediments.

\subsection{Temporal variability in diurnal $\mathrm{NO}_{3}$ dynamics: the role of changing meteorological conditions}

During Spring 2008 the diurnal $\mathrm{NO}_{3}$ cycle was much smaller and the phase of the cycle was much more variable than the dynamics observed in Spring 2007. The variability in the diurnal $\mathrm{NO}_{3}$ dynamics between the years demonstrates how diurnal dynamics can be affected by both antecedent catchment conditions and meteorological events, such as droughts.

Water from the upper soil horizons acted as a source of $\mathrm{NO}_{3}$ to the stream in both the Upper and Lower Hafren in Spring 2007. There were higher $\mathrm{NO}_{3}$ concentrations at the Upper Hafren in Spring 2007, compared to Spring 2008, which may be the residual effect of $\mathrm{NO}_{3}$ mineralised from the upper soil horizons after the end of the 2006 drought. As stated previously, Plynlimon experienced prolonged drought conditions between 2004 and 2006, which was then followed by one of the wettest summers on record, resulting in significantly elevated flow within the Hafren catchment in July 2007 (Fig. 2, see Sect. 2.2). Although mineralisation is limited by moisture stress during drought conditions, increased soil water $\mathrm{NO}_{3}$ concentrations can occur as a result of increased evapotranspiration and reduced $\mathrm{NO}_{3}$ uptake by drought-stressed vegetation (Reynolds and Edwards, 1995). Large amounts of $\mathrm{NO}_{3}$ can then be leached into the stream in the immediate post-drought period as a consequence of mineralisation stimulation on re-wetting (Reynolds and Edwards, 1995). This effect was evident in the long-term data set. Sharp peaks in $\mathrm{NO}_{3}$ concentrations were observed in both the Upper and Lower Hafren $\mathrm{NO}_{3}$ time series in the winter of 1996-1997 associated with the termination of the 1995-1996 drought, with similar peaks, although not as pronounced, in the winter of 2006-2007 (Fig. 3). In Spring 2007, there was a positive relationship between $\mathrm{NO}_{3}$ and flow and between $\mathrm{NO}_{3}$ and two other soil-water-derived determinands, $\mathrm{Al}$ and DOC, meaning that when a higher proportion of streamwater was derived from upper soil horizons, $\mathrm{NO}_{3}$ concentrations increased. Although the streamwater $\mathrm{NO}_{3}$ data between June and July 2007 are limited in number due to a monitoring equipment malfunction, it is likely that the elevated flows experienced over this time resulted in a flushing of $\mathrm{NO}_{3}$ from the enriched soils into the streamwater (Reynolds and Edwards, 1995), such that by 2008 the soils' $\mathrm{NO}_{3}$ concentrations had returned to pre-drought levels. Consequently, there was reduced $\mathrm{NO}_{3}$ available for delivery to the stream in Spring 2008, in comparison to Spring 2007, and thus $\mathrm{NO}_{3}$ concentrations were lower.

The diurnal dynamics in Spring 2007 would have also been affected by the optimal meteorological conditions over this period, in comparison to the conditions experienced in the Spring 2008. The mean flow over the Spring 2007 period was significantly lower than the mean flow in Spring 2008, $0.06 \mathrm{~m}^{3} \mathrm{~s}^{-1}$ compared to $0.10 \mathrm{~m}^{3} \mathrm{~s}^{-1}$. In addition, the variability in flow over Spring 2007 was significantly reduced, 0.02 to $0.28 \mathrm{~m}^{3} \mathrm{~s}^{-1}$, compared to 0.04 to $0.71 \mathrm{~m}^{3} \mathrm{~s}^{-1}$ in 2008 . Air temperatures were also significantly higher in Spring 2007, with mean air temperature of $6.4{ }^{\circ} \mathrm{C}$ compared to only $3.6^{\circ} \mathrm{C}$ in Spring 2008. Consequently, uptake would likely have been enhanced in Spring 2007, as $\mathrm{NO}_{3}$ removal is most efficient in small headwater streams at low flows due to the longer water residence times (Fig. 2; Dawson et al., 2001; Ranalli and Macalady, 2010). The higher temperatures in the Spring 2007 period may have also promoted increased biological activity and together with the higher $\mathrm{NO}_{3}$ concentrations in the stream at this time, linked to the 2004-2006 drought, may also have enhanced biofilm growth during this period.

The impact of drought conditions on the diurnal $\mathrm{NO}_{3}$ cycle has important implications when considering the impact of future climate variability on catchment $\mathrm{NO}_{3}$ dynamics. The analysis of the 2007 and 2008 data suggests that extreme meteorological events, the frequency of which are predicted to increase in the UK (Marsh et al., 2007), can result in enhanced diurnal cycling of $\mathrm{NO}_{3}$, with maximum amplitude 
of the diurnal cycle over two times higher in Spring 2007 compared to Spring 2008, and consequently cause these short-term dynamics to form a stronger component of the complete $\mathrm{NO}_{3}$ time series. The interpretation of short-term data series needs caution if there are no long-term data to put them in context.

\section{Conclusions}

There is no clear evidence that the long-term declining trends in streamwater $\mathrm{NO}_{3}$ concentrations are driven by declining atmospheric $\mathrm{N}$ deposition alone, because the increasing trend in atmospheric deposition between 1983 and 1997 was not reflected in the streamwater $\mathrm{NO}_{3}$ concentrations. This is consistent with findings in other systems, where declining streamwater $\mathrm{NO}_{3}$ trends do not follow deposition reductions (see e.g. Goodale et al., 2003; Bernhardt et al., 2005, 2012), but are instead linked to features such as recovery from catchment disturbance and presence of organic debris dams. In the Hafren, increased $\mathrm{N}$ uptake caused by increasing temperatures and increased denitrification stimulated by increasing streamwater DOC concentrations have been identified as possible contributory factors in the declining streamwater $\mathrm{NO}_{3}$ concentrations. Further work is needed to fully understand the mechanisms controlling the coupling of $\mathrm{C}$ and $\mathrm{N}$ in this river system. The seasonality in the streamwater $\mathrm{NO}_{3}$ time series was linked to flow and catchment biological activity and this now seems well established as a general rule for a majority of catchments. The diurnal $\mathrm{NO}_{3}$ cycling in the Upper Hafren was controlled by instream autotrophic assimilation, and the dynamics at the Lower Hafren were a composite of the advected and dispersed signal from the upstream site and changes in $\mathrm{NO}_{3}$ processing in the forested reaches of the catchment. The importance of autotrophic $\mathrm{NO}_{3}$ uptake in diurnal variations in streamwater $\mathrm{NO}_{3}$ concentrations has also been noted in other studies (Mulholland et al., 2006; Heffernan and Cohen, 2010). In upland systems with limited anthropogenic influences, this type of diurnal $\mathrm{NO}_{3}$ cycle is likely to form a key component of the streamwater $\mathrm{NO}_{3}$ dynamics. Therefore these diurnal dynamics should be considered when designing low-frequency sampling programmes, because the time of day at which the samples are collected will influence the measured $\mathrm{NO}_{3}$ concentration, and could subsequently affect any conclusions drawn about the system. The enhanced diurnal $\mathrm{NO}_{3}$ cycling observed in the catchment in 2007 as a result of the optimal conditions in the post-drought period high temperatures, low flows and increased $\mathrm{NO}_{3}$ availability - has implications when considering the importance of diurnal $\mathrm{NO}_{3}$ variations to the overall $\mathrm{NO}_{3}$ cycle under future climate projections.

The non-stationary time-series decomposition tool DHR proved extremely useful in unravelling the complexity observed within the $\mathrm{NO}_{3}$ time series. As the technique breaks the time series down into component parts, the drivers of the different observed dynamics could be reviewed individually. In addition, as the method allows for non-stationarity within the time series, the changing dynamics of the system over time could be assessed. Full validation of the statistically modelled diurnal dynamics requires hourly measurements to ensure that the diurnal peaks and minimums were captured. However, high-frequency monitoring is extremely expensive. Given the climatic variability experienced in the UK, this poses challenges, because with only short-term monitoring is it difficult to determine whether the observed diurnal dynamics are "normal" or "atypical". Work deploying in situ UV spectrophotometers has demonstrated that such instruments provide extremely reliable $\mathrm{NO}_{3}$ measurements for a range of different catchments and climatic settings (Chapin et al., 2004; Johnson et al., 2006; Sakamoto et al., 2009; Wade et al., 2012; Zielinski et al., 2011), and could provide the answer for robust long-term high-frequency $\mathrm{NO}_{3}$ monitoring at Plynlimon and elsewhere. The importance of studying all nutrient fractions, in particular the organic fraction, should not be overlooked (e.g. Durand et al., 2011). In this study it was possible to measure all dissolved $\mathrm{N}$ fractions because the samples were returned to the laboratory for analysis, but in situ instruments are currently only available for specific determinands. In addition, automated in situ sample filtration remains a challenge (Wade et al., 2012). Therefore, researchers need to consider the value of high-frequency data, without information on all nutrient fractions.

Data availability/resolution has been recognised as one of the main limitations of hydrochemical studies (e.g. Bouwman et al., 2013; Kirchner et al., 2004). This study demonstrates that long-term water quality data are needed to put the short-term, high-frequency data into context, and to identify the role of both gradually changing influences and sporadic rare events such as droughts. The combination of the two monitoring approaches allows hypotheses about the controls on stream $\mathrm{NO}_{3}$ dynamics to be tested more rigorously, and for new research questions to be generated. Together the long-term and high-frequency data allow inferences about underlying processes controlling the observed $\mathrm{NO}_{3}$ dynamics to be made - for instance at Plynlimon the seasonal $\mathrm{NO}_{3}$ trends show that declining atmospheric $\mathrm{N}$ deposition is having an effect, with successive smaller seasonal $\mathrm{NO}_{3}$ maximums, and the diurnal variations show the influence of instream processing, demonstrating that the river is not simply a conduit. Without associated environmental data, such as discharge, rainfall and meteorological data, it would have been impossible to elucidate the principal mechanisms operating within the Hafren system. Therefore, there is a need to think pragmatically about monitoring, as the value of the high-frequency data is determined by the system understanding that it can provide. Researchers have to ask themselves how much they will really be able to learn 
about the system from only a short period of intensive monitoring. Instead researchers should consider undertaking high-frequency monitoring in catchments with already well-established monitoring networks, such as Plynlimon, where the high-frequency data can be best interpreted. The continued and more widespread collection of high resolution $\mathrm{NO}_{3}$ data from a variety of catchments will further enhance our understanding of watershed dynamics and allow the quantification of the importance of diurnal cycling and the role of instream processing.

Acknowledgements. All data reported in this paper are freely accessible via the NERC EIDC (Neal et al., 2013a, b). The authors would like to thank many Centre for Ecology and Hydrology analysts and field workers who over many years have provided the samples and analysis for $\mathrm{NO}_{3}$. They include Christopher Smith, Margaret Neal and Phil Rowland who led the analytical teams that comprised Linda Armstrong, Heather Wickham, Sarah Harman, Clive Woods, Darren Sleep, Sarah Thacker, Hayley Guyatt and Alan Lawlor. For the field support and initial processing of the samples and data, we thank Sue and Tim Hill, Bron Williams, Jeremy Wilkinson and Simon Grant together with Mark Robinson for hydrological aspects.

The data resource comes directly via Centre for Ecology and Hydrology core science within the Natural Environmental Research Council as does their staffing component. Funding for the analysis of the data was provided by EPSRC (Grant Number EP/G019967/1) with regard to the Reading research component.

Edited by: B. A. Bergamaschi

\section{References}

Bailey E.: Living Landscapes - The most important hill in Britain, Natural World, Winter, 2010, 15-18, 2010

Becker, S., Halsall, C. J., Tych, W., Hung, H., Attewell, S., Blanchard, P., Li, H., Fellin, P., Stern, G., Billeck, B., and Friesen, S.: Resolving the long-term trends of polycyclic aromatic hydrocarbons in the Canadian Arctic atmosphere, Environ. Sci. Technol., 40, 3217-3222, 2006.

Bernal, S., Hedin, L. O., Likens, G. E., Gerber, S., and Buso, D. C.: Complex response of the forest nitrogen cycle to climate change, Proc. Natl. Acad. Sci. USA, 109, 3406-3411, doi:10.1073/pnas.1121448109, 2012.

Bernhardt, E. S. and Likens, G. E.: Dissolved organic carbon enrichment alters nitrogen dynamics in a forest stream, Ecology, 83, 1689-1700, 2002.

Birgand, F., Skaggs, R. W., Chescheir, G. M., and Gilliam, J. W.: Nitrogen removal in streams of agricultural catchments - A literature review, Crit. Rev. Environ. Sci. Technol., 37, 381-487, 2007.

Bouwman, A. F., Bierkens, M. F. P., Griffioen, J., Hefting, M. M., Middelburg, J. J., Middelkoop, H., and Slomp, C. P.: Nutrient dynamics, transfer and retention along the aquatic continuum from land to ocean: towards integration of ecological and biogeochemical models, Biogeosciences, 10, 1-22, doi:10.5194/bg-10-1-2013, 2013.
Brandt, C., Robinson, M., and Finch, J. W.: Anatomy of a catchment: the relation of physical attributes of the Plynlimon catchments to variations in hydrology and water status, Hydrol Earth Syst Sc, 8, 345-354, 2004.

Burt, T. P., Howden, N. J. K., Worrall, F., and Whelan, M. J.: Importance of long-term monitoring for detecting environmental change: lessons from a lowland river in south east England, Biogeosciences, 5, 1529-1535, doi:10.5194/bg-5-1529-2008, 2008.

Chapin, T. P., Caffrey, J. M., Jannasch, H. W., Coletti, L. J., Haskins, J. C., and Johnson, K. S.: Nitrate sources and sinks in Elkhorn Slough, California: Results from long-term continuous in situ nitrate analyzers, Estuaries, 27, 882-894, 2004.

Chapman, P. J., Reynolds, B., and Wheater, H. S.: Experimental Investigation of Potassium and Nitrate Dynamics in A Headwater Stream in Mid-Wales, Chem. Ecol., 13, 1-19, 1996.

Chapman, P. J., Edwards, A. C., Reynolds, B., and Neal, C.: The nitrogen composition of streams draining grassland and forested catchments: influence of afforestation on the nitrogen cycle in upland ecosystems, in: Impact of Land Use Change on Nutrient Loads from Diffuse Sources, edited by: Heathwaite A. L., Proceedings of IUGG 99 Symposium HS3, July 1999, IAHS Publication Number 257, International Association of Hydrological Sciences Press, Wallingford, Oxfordshire, OX10 8BB, UK, ISBN 1-901502-95-3, 1999.

Chapman, P. J., Edwards, A. C., and Cresser, M. S.: The nitrogen composition of streams in upland Scotland: some regional and seasonal differences, Sci Total Environ, 265, 65-83, doi:10.1016/s0048-9697(00)00650-1, 2001.

Chappell, N. A. and Tych, W.: Identifying step changes in single streamflow and evaporation records due to forest cover change, Hydrol. Process., 26, 100-116, doi:10.1002/hyp.8115, 2012.

Chapra, S. C.: Surface Water-Quality Modeling, McGraw-Hill Series in Water Resources and Environmental Engineering, The McGraw-Hill Companies Inc., Singapore, 844 pp., 1997.

Ciavatta, S. and Pastres, R.: Exploring the long-term and interannual variability of biogeochemical variables in coastal areas by means of a data assimilation approach , Estuar. Coast. Shelf. S., 91, 411422, doi:10.1016/j.ecss.2010.11.006, 2011.

Cooper, D. M.: Some effects of sampling design on water quality estimation in streams, Hydrol. Sci. J., 49, 1055-1080, doi:10.1623/hysj.49.6.1055.55719, 2004.

Curtis, C. J., Emmett, B. A., Grant, H., Kernan, M., Reynolds, B., and Shilland, E.: Nitrogen saturation in UK moorlands: the critical role of bryophytes and lichens in determining retention of atmospheric N deposition, J. Appl. Ecol., 42, 507-517, doi:10.1111/j.1365-2664.2005.01029.x, 2005.

Dawson, C. W. and Wilby, R. L.: Hydrological modelling using artificial neural networks, Prog. Phys. Geog., 25, 80-108, 2001.

DEFRA: British survey of fertiliser practice: Fertiliser use on farm crops for crop year 2011, DEFRA, 103, 2012.

Dise, N. B., Rothwell, J. J., Gauci, V., van der Salm, C., and de Vries, W.: Predicting dissolved inorganic nitrogen leaching in European forests using two independent databases, Sci. Total. Environ., 407, 1798-1808, doi:10.1016/j.scitotenv.2008.11.003, 2009.

Duff, J. H., Tesoriero, A. J., Richardson, W. B., Strauss, E. A., and Munn, M. D.: Whole-stream response to nitrate loading in three 
streams draining agricultural landscapes, J. Environ. Qual., 37, 1133-1144, doi:10.2134/jeq2007.0187, 2008.

Environment Agency: Review of 2007 summer floods, available at: http://www.environment-agency.gov.uk/research/library/ publications/33887.aspx, (last access: 7 August 2013), 58 pp., 2007.

Environment Agency: River Basin Management Plan: Severn River Basin District Environment Agency, available at: http://www. environment-agency.gov.uk/research/planning/124941.aspx, (last access: 7 August 2013), 65 pp., 2009.

Evans, C. D. and Monteith, D. T.: Chemical trends at lakes and streams in the UK Acid Waters Monitoring Network, 1988-2000: Evidence for recent recovery at a national scale, Hydrol. Earth Syst. Sc., 5, 351-366, 2001.

Ferrant, S., Laplanche, C., Durbe, G., Probst, A., Dugast, P., Durand, P., Sanchez-Perez, J. M., and Probst, J. L.: Continuous measurement of nitrate concentration in a highly event-responsive agricultural catchment in south-west of France: is the gain of information useful? Hydrol. Process., 27, 1751-1763, doi:10.1002/hyp.9324, 2012.

Foster, H. J., Lees, M. J., Wheater, H. S., Neal, C., and Reynolds, B.: A hydrochemical modelling framework for combined assessment of spatial and temporal variability in stream chemistry: application to Plynlimon, Wales, Hydrol. Earth Syst. Sc., 5, 49-58, 2001.

Frame, J. L.: Ecology of acidification and recovery in Welsh upland streams, PhD, School of Geography, Earth Environ. Sci., University of Birmingham, 244 pp., 2010.

Galloway, J., Dentener, F. J., Capone, D. G., Boyer, E. W., Howarth, R. W., Seitzinger, S. P., Asner, G. P., Cleveland, C. C., Green, P. A., Holland, E. A., Karl, D. M., Michaels, A. F., Porter, J. H., Townsend, A. R., and Vöosmarty, C. J.: Nitrogen cycles: past, present, and future, Biogeochemistry, 70, 153-226, 2004.

Godsey, S. E., Aas, W., Clair, T. A., de Wit, H. A., Fernandez, I. J., Kahl, J. S., Malcolm, I. A., Neal, C., Neal, M., Nelson, S. J., Norton, S. A., Palucis, M. C., Skjelkvale, B. L., Soulsby, C., Tetzlaff, D., and Kirchner, J. W.: Generality of fractal 1/f scaling in catchment tracer time series, and its implications for catchment travel time distributions, Hydrol. Process., 24, 1660-1671, doi:10.1002/hyp.7677, 2010.

Graeber, D., Gelbrecht, J., Kronvang, B., Gücker, B., Pusch, M. T., and Zwirnmann, E.: Technical Note: Comparison between a direct and the standard, indirect method for dissolved organic nitrogen determination in freshwater environments with high dissolved inorganic nitrogen concentrations, Biogeosciences, 9, 4873-4884, doi:10.5194/bg-9-4873-2012, 2012.

Green, S.,and Marsh, T. J.: A consideration of rainfall, runoff and losses at Plynlimon in the context of long term hydrological variability in the UK and maritime Western Europe, Hydrol. Earth Syst. Sc., 1, 399-407, 10.5194/hess-1-399-1997, 1997.

Halliday, S. J., Wade, A. J., Skeffington, R. A., Neal, C., Reynolds, B., Rowland, P., Neal, M., and Norris, D.: An analysis of longterm trends, seasonality and short-term dynamics in water quality data from Plynlimon, Wales, Sci. Total. Environ., 434, 186-200, 2012.

Heffernan, J. B. and Cohen, M. J.: Direct and indirect coupling of primary production and diel nitrate dynamics in a subtropical spring-fed river, Limnol. Oceanogr., 55, 677-688, doi:10.4319/lo.2010.55.2.0677, 2010 .
Herrman, K. S., Bouchard, V., and Moore, R. H.: An assessment of nitrogen removal from headwater streams in an agricultural watershed, northeast Ohio, USA, Limnol. Oceanogr., 53, 25732582, doi:10.4319/lo.2008.53.6.2573, 2008.

Hood, E., Gooseff, M. N., and Johnson, S. L.: Changes in the character of stream water dissolved organic carbon during flushing in three small watersheds, Oregon, J. Geophys. Res.-Biogeo., 111, G01007, doi:10.1029/2005jg000082, 2006.

Hudson, J. A., Crane, S. B., and Blackie, J. R.: The Plynlimon water balance 1969-1995: the impact of forest and moorland vegetation on evaporation and streamflow in upland catchments, Hydrol. Earth Syst. Sci., 1, 409-427, doi:10.5194/hess-1-4091997, 1997a.

Hudson, J. A., Gilman, K., and Calder, I. R.: Land use and water issues in the uplands with reference to the Plynlimon study, Hydrol. Earth Syst. Sci., 1, 389-397, doi:10.5194/hess-1-389-1997, 1997b.

Jarvie, H. P., Whitton, B. A., and Neal, C.: Nitrogen and phosphorus in east coast British rivers: Speciation, sources and biological significance, Sci. Total Environ., 210, 79-109, doi:10.1016/s0048-9697(98)00109-0, 1998.

Johnson, K. S., Coletti, L. J., and Chavez, F. P.: Diel nitrate cycles observed with in situ sensors predict monthly and annual new production, Deep-Sea Res. Part I, 53, 561-573, doi:10.1016/j.dsr.2005.12.004, 2006.

Keery, J., Binley, A., Crook, N., and Smith, J. W. N.: Temporal and spatial variability of groundwater-surface water fluxes: Development and application of an analytical method using temperature time series, J. Hydrol., 336, 1-16, 2007.

Kirby, C., Newson, M. D., and Gilman , K.: Plynlimon research: The first two decades, Institute of Hydrology, Report No. 109, Wallingford, 188 pp., 1991.

Kirchner, J. W., Feng, X. H., Neal, C., and Robson, A. J.: The fine structure of water-quality dynamics: the (highfrequency) wave of the future, Hydrol. Process., 18, 1353-1359, doi:10.1002/hyp.5537, 2004.

Langan, S. J., Wade, A. J., Smart, R., Edwards, A. C., Soulsby, C., Billett, M. F., Jarvie, H. P., Cresser, M. S., Owen, R., and Ferrier, R. C.: The prediction and management of water quality in a relatively unpolluted major Scottish catchment: Current issues and experimental approaches, Sci. Total Environ., 194, 419-435, doi:10.1016/s0048-9697(96)05380-6, 1997.

Ledger, M. E. and Hildrew, A. G.: The ecology of acidification and recovery: changes in herbivore-algal food web linkages across a stream pH gradient, Environ. Pollut., 137, 103-118, 2005.

Marc, V. and Robinson, M.: The long-term water balance (19722004) of upland forestry and grassland at Plynlimon, mid-Wales, Hydrol. Earth Syst. Sc., 11, 44-60, 2007.

Marsh, T.: The 2004-2006 drought in southern Britain, Weather, 62, 191-196, doi:10.1002/wea.99, 2007.

Marsh, T., Cole, G., and Wilby, R.: Major droughts in England and Wales, 1800-2006, Weather, 62, 87-93, doi:10.1002/wea.67, 2007.

Marsh, T. J.: The 1995 UK drought - A signal of climatic instability?, Proceedings of the Institution of Civil Engineers-Water Maritime and Energy, 118, 189-195, 1996.

Marsh, T. J. and Hannaford, J.: UK Hydrometric Register, Hydrological data UK series, Centre for Ecology Hydrology, 2008. 
Monteith, D. T., Evans, C. D., and Reynolds, B.: Are temporal variations in the nitrate content of UK upland freshwaters linked to the North Atlantic Oscillation?, Hydrol. Process., 14, 1745-1749, 10.1002/1099-1085(200007)14:10<1745::AIDHYP116>3.0.CO;2-O, 2000.

Mulholland, P. J., Thomas, S. A., Valett, H. M., Webster, J. R., and Beaulieu, J.: Effects of light on NO3- uptake in small forested streams: diurnal and day-to-day variations, J. N. Am. Benthol. Soc., 25, 583-595, 10.1899/08873593(2006)25[583:EOLONU]2.0.CO;2, 2006.

Neal, C.: A view of water quality from the Plynlimon watershed, Hydrol Earth Syst Sc, 1, 743-753, doi:10.5194/hess-1-743-1997, 1997.

Neal, C.: Assessing environmental impacts on stream water quality: the use of cumulative flux and cumulative flux difference approaches to deforestation of the Hafren Forest, mid-Wales, Hydrol. Earth Syst Sc., 6, 421-432, 2002.

Neal, C.: The water quality functioning of the upper River Severn, Plynlimon, mid-Wales: issues of monitoring, process understanding and forestry, Hydrol. Earth Syst. Sc., 8, 521-532, doi:10.5194/hess-8-521-2004, 2004.

Neal, C. and Jarvie, H. P.: Agriculture, community, river eutrophication and the Water Framework Directive, Hydrol. Process., 19, 1895-1901, doi:10.1002/hyp.5903, 2005.

Neal, C., Reynolds, B., Neal, M., Pugh, B., Hill, L., and Wickham, H.: Long-term changes in the water quality of rainfall, cloud water and stream water for moorland, forested and clear-felled catchments at Plynlimon, mid-Wales, Hydrol. Earth Syst. Sc., 5, 459-476, 2001.

Neal, C., Reynolds, B., Neal, M., Hill, L., Wickham, H., and Pugh, B.: Nitrogen in rainfall, cloud water, throughfall, stemflow, stream water and groundwater for the Plynlimon catchments of mid-Wales, Sci. Total Environ., 314, 121-151, doi:10.1016/S0048-9697(03)00100-1, 2003.

Neal, C., Robson, A. J., Neal, M., and Reynolds, B.: Dissolved organic carbon for upland acidic and acid sensitive catchments in mid-Wales, J. Hydrol., 304, 203-220, doi:10.1016/j.jhydrol.2004.07.030, 2005.

Neal, C., Robinson, M., Reynolds, B., Neal, M., Rowland, P., Grant, S., Norris, D., Williams, B., Sleep, D., and Lawlor, A.: Hydrology and water quality of the headwaters of the River Severn: Stream acidity recovery and interactions with plantation forestry under an improving pollution climate, Sci. Total Environ., 408, 5035-5051, doi:10.1016/j.scitotenv.2010.07.047, 2010.

Neal, C., Reynolds, B., Norris, D., Kirchner, J. W., Neal, M., Rowland, P., Wickham, H., Harman, S., Armstrong, L., Sleep, D., Lawlor, A., Woods, C., Williams, B., Fry, M., Newton, G., and Wright, D.: Three decades of water quality measurements from the Upper Severn experimental catchments at Plynlimon, Wales: an openly accessible data resource for research, modelling, environmental management and education, Hydrol. Process., 25, 3818-3830, doi:10.1002/hyp.8191, 2011.

Neal, C., Reynolds, B., Rowland, P., Norris, D., Kirchner, J. W., Neal, M., Sleep, D., Lawlor, A., Woods, C., Thacker, S., Guyatt, H., Vincent, C., Hockenhull, K., Wickham, H., Harman, S., and Armstrong, L.: High-frequency water quality time series in precipitation and streamflow: From fragmentary signals to scientific challenge, Sci. Total Environ., 434, 3-12, 2012.
Neal, C., Kirchner, J., and Reynolds, B.: Plynlimon research catchment hydrochemistry, NERC-Environmental Information Data Centre, doi:10.5285/44095e17-43b0-45d4-a781-aab4f72da025, 2013a.

Neal, C., Kirchner, J., and Reynolds, B.: Plynlimon research catchment high-frequency hydrochemistry data, NERCEnvironmental Information Data Centre, doi:10.5285/551a10aeb8ed-4ebd-ab38-033dd597a374, 2013b.

Neal, C., Reynolds, B., Kirchner, J. W., Rowland, P., Norris, D., Sleep, D., Lawlor, A., Woods, C., Thacker, S., Guyatt, H., Vincent, C., Lehto, K., Grant, S., Williams, J., Neal, M., Wickham, H., Harman, S., and Armstrong, L.: High-frequency precipitation and stream water quality time series from Plynlimon, Wales: an openly accessible data resource spanning the periodic table, Hydrol. Process., 27, 2531-2539, doi:10.1002/hyp.9814, 2013c.

Ness, L., Neal, C., Davies, T. D., and Reynolds, B.: Impacts of the North Atlantic Oscillation on stream water chemistry in mid-Wales, Hydrol. Earth Syst. Sc., 8, 409-421, 2004.

Newson, M. D.: The physiography, deposits and vegetation of the Plynlimon catchments - A synthesis of published work and initial findings, Institute of Hydrology, Report No.30, Wallingford, 60 pp., 1976

Newson, M. D. and Harrison, J. G.: Channel studies in the Plynlimon experimental catchments, Institute of Hydrology, Report No.47, Wallingford, 62 pp., 1978.

Nimick, D. A., Gammons, C. H., and Parker, S. R.: Diel biogeochemical processes and their effect on the aqueous chemistry of streams: A review, Chem. Geol., 283, 3-17, doi:10.1016/j.chemgeo.2010.08.017, 2011.

Palmer-Felgate, E. J., Jarvie, H. P., Williams, R. J., Mortimer, R. J. G., Loewenthal, M., and Neal, C.: Phosphorus dynamics and productivity in a sewage-impacted lowland chalk stream, J. Hydrol., 351, 87-97, doi:10.1016/j.jhydrol.2007.11.036, 2008.

Parker, S. R., Gammons, C. H., Poulson, S. R., and DeGrandpre, M. D.: Diel variations in stream chemistry and isotopic composition of dissolved inorganic carbon, upper Clark Fork River, Montana, USA, Appl. Geochem., 22, 1329-1343, doi:10.1016/j.apgeochem.2007.02.007, 2007.

Pattinson, S. N., Garcia-Ruiz, R., and Whitton, B. A.: Spatial and seasonal variation in denitrification in the Swale-Ouse system, a river continuum, Sci Total Environ, 210, 289-305, 10.1016/s0048-9697(98)00019-9, 1998.

Pedregal, D. J. and Trapero, J. R.: Electricity prices forecasting by automatic dynamic harmonic regression models, Energ. Convers. Manage., 48, 1710-1719, doi:10.1016/j.enconman.2006.11.004, 2007.

Pellerin, B., Saraceno, J., Shanley, J., Sebestyen, S., Aiken, G., Wollheim, W., and Bergamaschi, B.: Taking the pulse of snowmelt: in situ sensors reveal seasonal, event and diurnal patterns of nitrate and dissolved organic matter variability in an upland forest stream, Biogeochemistry, 108, 183-198, doi:10.1007/s10533-011-9589-8, 2012.

Pellerin, B. A., Downing, B. D., Kendall, C., Dahlgren, R. A., Kraus, T. E. C., Saraceno, J., Spencer, R. G. M., and Bergamaschi, B. A.: Assessing the sources and magnitude of diurnal nitrate variability in the San Joaquin River (California) with an in situ optical nitrate sensor and dual nitrate isotopes, Freshwater Biol., 54, 376-387, doi:10.1111/j.13652427.2008.02111.x, 2009. 
Peterson, B. J., Wollheim, W. M., Mulholland, P. J., Webster, J. R., Meyer, J. L., Tank, J. L., Marti, E., Bowden, W. B., Valett, H. M., Hershey, A. E., McDowell, W. H., Dodds, W. K., Hamilton, S. K., Gregory, S., and Morrall, D. D.: Control of nitrogen export from watersheds by headwater streams, Science, 292, 86-90, doi:10.1126/science.1056874, 2001.

Ranalli, A. J. and Macalady, D. L.: The importance of the riparian zone and in-stream processes in nitrate attenuation in undisturbed and agricultural watersheds $-\mathrm{A}$ review of the scientific literature, J. Hydrol., 389, 406-415, doi:10.1016/j.jhydrol.2010.05.045, 2010.

Reynolds, B., Hornung, M., and Hughes, S.: Chemistry of streams draining grassland and forest catchments at Plynlimon, mid-Wales, Hydrolog. Sci. J., 34, 667-686, doi:10.1080/02626668909491374, 1989.

Reynolds, B., and Edwards, A.: Factors influencing dissolved nitrogen concentrations and loadings in upland streams of the UK, Agri. Water Manage., 27, 181-202, doi:10.1016/03783774(95)01146-a, 1995.

Reynolds, B., Lowe, J. A. H., Smith, R. I., Norris, D. A., Fowler, D., Bell, S. A., Stevens, P. A., and Ormerod, S. J.: Acid deposition in Wales: the results of the 1995 Welsh Acid Waters Survey, Environ. Pollut., 105, 251-266, doi:10.1016/s0269-7491(98)00218-8, 1999.

Romanowicz, R., Young, P., Brown, P., and Diggle, P.: A recursive estimation approach to the spatio-temporal analysis and modelling of air quality data, Environ. Modell. Softw., 21, 759-769, 2006.

Rusjan, S., Brilly, M., and Mikoš, M.: Flushing of nitrate from a forested watershed: An insight into hydrological nitrate mobilization mechanisms through seasonal high-frequency stream nitrate dynamics, J. Hydrol., 354, 187-202, 2008.

Rusjan, S., and Mikos, M.: Seasonal variability of diurnal in-stream nitrate concentration oscillations under hydrologically stable conditions, Biogeochemistry, 97, 123-140, doi:10.1007/s10533009-9361-5, 2010.

RWE npower: History of Pembroke, available at: http: //www.rwe.com/web/cms/en/1628694/rwe-npower/about-us/ our-businesses/power-generation/pembroke/, last access: 07 August 2013.

Saraceno, J. F., Pellerin, B. A., Downing, B. D., Boss, E., Bachand, P. A. M., and Bergamaschi, B. A.: High-frequency in situ optical measurements during a storm event: Assessing relationships between dissolved organic matter, sediment concentrations, and hydrologic processes, J. Geophys. Res.-Biogeo., 114, G00f09, doi:10.1029/2009jg000989, 2009.

Scholefield, D., Le Goff, T., Braven, J., Ebdon, L., Long, T., and Butler, M.: Concerted diurnal patterns in riverine nutrient concentrations and physical conditions, Sci. Total Environ., 344, 201-210, doi:10.1016/j.scitotenv.2005.02.014, 2005.

Shand, P., Haria, A. H., Neal, C., Griffiths, K. J., Gooddy, D. C., Dixon, A. J., Hill, T., Buckley, D. K., and Cunningham, J. E.: Hydrochemical heterogeneity in an upland catchment: further characterisation of the spatial, temporal and depth variations in soils, streams and groundwaters of the Plynlimon forested catchment, Wales, Hydrol. Earth Syst. Sc., 9, 621-644, doi:10.5194/hess-9-621-2005, 2005.

Shand, P., Darbyshire, D. P. F., Gooddy, D., and Haria, A. H.: Sr$87 / \mathrm{Sr}-86$ as an indicator of flowpaths and weathering rates in the
Plynlimon experimental catchments, Wales, UK, Chem. Geol., 236, 247-265, doi:10.1016/j.chemgeo.2006.09.012, 2007.

Shilland, E. M., Irvine, L., Malcolm, I. A., Marazzi, L., Panizzo, V. N., and Salgado, J.: The United Kingdom Acid Waters Monitoring Network Data Report for 2010-2011 (year 23), DEFRA, London, 239 pp., 2012.

Smart, R. P., Soulsby, C., Neal, C., Wade, A., Cresser, M. S., Billett, M. F., Langan, S. J., Edwards, A. C., Jarvie, H. P., and Owen, R.: Factors regulating the spatial and temporal distribution of solute concentrations in a major river system in NE Scotland, Sci. Total Environ., 221, 93-110, doi:10.1016/s0048-9697(98)00196-x, 1998.

Smith, V. H., Tilman, G. D., and Nekola, J. C.: Eutrophication: impacts of excess nutrient inputs on freshwater, marine, and terrestrial ecosystems, Environ Pollut, 100, 179-196, doi:10.1016/s0269-7491(99)00091-3, 1999.

Soulsby, C., Gibbins, C., Wade, A. J., Smart, R., and Helliwell, R.: Water quality in the Scottish uplands: a hydrological perspective on catchment hydrochemistry, Sci. Total Environ., 294, 73-94, Piis0048-9697(02)00057-8, doi:10.1016/s0048-9697(02)000578, 2002.

Stevens, C. J., Dise, N. B., Gowing, D. J. G., and Mountford, J. O.: Loss of forb diversity in relation to nitrogen deposition in the UK: regional trends and potential controls, Glob. Change Biol., 12, 1823-1833, doi:10.1111/j.1365-2486.2006.01217.x, 2006.

Sutton, M. A., Howard, C. M., Erisman, J. W., Billen, G., Bleeker, A., Grennfelt, P., van Grinsven, H., and Grizzetti, B.: The European Nitrogen Assessment: Sources, Effects and Policy Perspectives New York, Cambridge University Press, Cambridge, 664 pp., 2011.

Taylor, C. J., Pedregal, D. J., Young, P. C., and Tych, W.: Environmental time series analysis and forecasting with the Captain toolbox, Environ. Modell. Softw., 22, 797-814, doi:10.1016/j.envsoft.2006.03.002, 2007.

UK-NEA: The UK National Ecosystem Assessment: Synthesis of the Key Findings, UNEP-WCMC, Cambridge, 97 pp., 2011.

Wade, A. J., Durand, P., Beaujouan, V., Wessel, W. W., Raat, K. J., Whitehead, P. G., Butterfield, D., Rankinen, K., and Lepisto, A.: A nitrogen model for European catchments: INCA, new model structure and equations, Hydrol. Earth Syst. Sc., 6, 559-582, 2002.

Wade, A. J., Palmer-Felgate, E. J., Halliday, S. J., Skeffington, R. A., Loewenthal, M., Jarvie, H. P., Bowes, M. J., Greenway, G. M., Haswell, S. J., Bell, I. M., Joly, E., Fallatah, A., Neal, C., Williams, R. J., Gozzard, E., and Newman, J. R.: Hydrochemical processes in lowland rivers: insights from in situ, high-resolution monitoring, Hydrol. Earth Syst. Sc., 16, 4323-4342, doi:10.5194/hess-16-4323-2012, 2012.

WFD: UK Environmental Standards and Conditions Report (Phase 1) - Final Report, UK Technical Advisory Group on the WFD, available at: http://www.wfduk.org/resources\%20/ uk-environmental-standards-and-conditions-report-phase-1 (last access; 07 August 2013), 73 pp., 2008.

Whitehead, P. G., Hill, T. J., and Neal, C.: Impacts of forestry on nitrogen in upland and lowland catchments: a comparison of the River Severn at Plynlimon in mid-Wales and the Bedford Ouse in south-east England using the INCA Model, Hydrol. Earth Syst. Sci., 8, 533-544, doi:10.5194/hess-8-533-2004, 2004. 
Wright, R. F., Alewell, C., Cullen, J. M., Evans, C. D., Marchetto, A., Moldan, F., Prechtel, A., and Rogora, M.: Trends in nitrogen deposition and leaching in acid-sensitive streams in Europe, Hydrol. Earth Syst. Sc., 5, 299-310, 2001.

Young, P.: Data-based mechanistic modelling of environmental, ecological, economic and engineering systems, Environ. Modell. Softw., 13, 105-122, doi:10.1016/s1364-8152(98)00011-5, 1998.
Young, P. C., Pedregal, D. J., and Tych, W.: Dynamic harmonic regression, J. Forecasting, 18, 369-394, doi:10.1002/(SICI)1099131X(199911)18:6<369::AID-FOR748>3.0.CO;2-K, 1999.

Young, P. C., Taylor, C. J., Tych, W., and Pedregal, D. J.: The Captain Toolbox, Centre for Research on Environmental Systems and Statistics, Lancaster University, UK, available at: www.es. lancs.ac.uk/cres/captain (last access: 07 August 2013), 2007. 